\title{
The Role of Partial Melting in the 15-Ma Geochemical Evolution of Gran Canaria: A Blob Model for the Canary Hotspot
}

\author{
by KAJ HOERNLE ${ }^{1}$ AND HANS-ULRICH SCHMINCKE \\ ${ }^{1}$ Earth Sciences, University of California, Santa Cruz, California 95064 \\ ${ }^{2}$ GEOMAR, Abteilung Vulkanologie, Wischhofstr. 1-3, D-2300 Kiel-14, Germany
}

(Received 14 October 1990; revised typescript accepted 6 October 1992)

\begin{abstract}
A BSTRACT
The subaerial portion of Gran Canaria, Canary Islands, was built by three cycles of volcanism: a Miocene Cycle (8.5-15 Ma), a Pliocene Cycle (1.8-6.0 Ma), and a Quaternary Cycle (1.8-0 Ma). Only the Pliocene Cycle is completely exposed on Gran Canaria; the early stages of the Miocene Cycle are submarine and the Quaternary Cycle is still in its initial stages. During the Miocene, $\mathrm{SiO}_{2}$ saturation of the mafic volcanics decreased systematically from tholeiite to nephelinite. For the Pliocene Cycle, $\mathrm{SiO}_{2}$ saturation increased and then decreased with decreasing age from nephelinite to tholeiite to nephelinite. $\mathrm{SiO}_{2}$ saturation increased from nephelinite to basanite and alkali basalt during the Quaternary. In each of these cycles, increasing melt production rates, $\mathrm{SiO}_{2}$ saturation, and concentrations of compatible elements, and decreasing concentrations of some incompatible elements are consistent with increasing degrees of partial melting in the sequence melilite nephelinite to tholeiite. The mafic volcanics from all three cycles were derived from $\mathrm{CO}_{2}$-rich garnet therzolite sources. Phlogopite, ilmenite, sulfide, and a phase with high partition coefficients for the light rare earth elements (LREE), $\mathrm{U}, \mathrm{Th}, \mathrm{Pb}, \mathrm{Nb}$, and $\mathrm{Zr}$, possibly zircon, were residual during melting to form the Miocene nephelinites through tholeiites; phlogopite, ilmenite, and sulfide were residual in the source of the Pliocene-Quaternary nephelinites through alkali basalts. Highly incompatible element ratios (e.g., $\mathrm{Nb} / \mathrm{U}, \mathrm{Pb} / \mathrm{Ce}, \mathrm{K} / \mathrm{U}, \mathrm{Nb} / \mathrm{Pb}, \mathrm{Ba} / \mathrm{Rb}, \mathrm{Zr} / \mathrm{Hf}, \mathrm{La} / \mathrm{Nb}, \mathrm{Ba} / \mathrm{Th}, \mathrm{Rb} / \mathrm{Nb}, \mathrm{K} / \mathrm{Nb}, \mathrm{Zr} / \mathrm{Nb}$, Th/Nb, Th/La, and $\mathrm{Ba} / \mathrm{La}$ ) exhibit extreme variations (in many cases larger than those reported for all other ocean island basalts), but these ratios correlate well with degree of melting. Survival of residual phases at higher degrees of melting during the Miocene Cycle and differences between major and trace element concentrations and melt production rates between the Miocene and Pliocene tholeiites suggest that the Miocene source was more fertile than the Pliocene-Quaternary source(s).

We propose a blob model to explain the multi-cycle evolution of Canary volcanoes and the temporal variations in chemistry and melt production within cycles. Each cycle of volcanism represents decompression melting of a discrete blob of plume material. Small-degree nephelinitic and basanitic melts are derived from the cooler margins of the blobs, whereas the larger-degree tholeiitic and alkali basaltic melts are derived from the hotter centers of the blobs. The symmetrical sequence of mafic volcanism for a cycle, from highly undersaturated to saturated to highly undersaturated compositions, reflects melting of the blob during its ascent beneath an island in the sequence upper margin-corelower margin. Volcanic hiatuses between cycles and within cycles represent periods when residual blob or cooler entrained shallow mantle material fill the melting zone beneath an island.
\end{abstract}

\section{INTRODUCTION}

The Canary Islands (Spain), situated off the coast of southern Morocco, form a roughly linear, $600-\mathrm{km}$ chain of seven volcanic islands, aligned in the direction of plate motion, which 
has been to the ENE. In his classic paper on the origin of the Hawaiian Islands, Wilson (1963) proposed that the Canary Islands were also formed by a mantle plume or 'hotspot'. Several features of the Canary Islands, however, are inconsistent with the classic mantle plume model developed for Hawaii, in which the lithosphere passes over a single narrow vertical conduit transporting hotter material from depth. These features include (1) the long volcanic history of the Canary chain and of individual islands in the chain (>20 Ma on the older islands), (2) low melt productivity for individual islands and the whole island chain, (3) large chemical diversity of volcanics and plutonics, (4) the temporal and spatial variation in geochemistry, and (5) multiple cycles of volcanism on the islands (for recent summaries, see Schmincke, 1982, 1990; Le Bas et al., 1986; Ancochea et al., 1990). For example, within the last 5000 years, each of the islands except La Gomera, one of the western islands, has been volcanically active. In contrast to what one would predict from a 'hotspot' type model, historic eruptions on Lanzarote, one of the oldest and the easternmost island, were primarily tholeiitic; whereas historic eruptions on La Palma, one of the two youngest and westernmost islands, were basanitic. Inconsistencies such as this have long fueled debate on whether the Canaries are indeed a hotspot track, although a better model has yet to be proposed (for a detailed discussion of alternative hypotheses for the origin of the Canary Islands, see Schmincke, 1976, 1982, 1990).

The extreme tectonic setting of the Canaries no doubt can explain some of these peculiarities. The Canaries are underlain by very old ocean crust formed in the Jurassic and thus the mechanical boundary layer will have a maximum thickness for oceanic lithosphere. This thick mechanical boundary layer is one possible explanation for the low Canarian melt production. The low buoyancy flux $(1 \mathrm{Mg} / \mathrm{s}$, estimated for the Canary and Madeira Hotspots combined; Sleep, 1990) no doubt also contributes to the low melt production rate (Hoernle \& Schmincke, this volume). Second, as a result of the proximity of the Canary Islands to the pole of rotation for the African plate, the rate of plate motion has been very low, for example $\sim 10 \mathrm{~mm} / \mathrm{yr}$ for the last $60 \mathrm{Ma}$ (Duncan, 1981; Morgan, 1983). Slow plate motion has no doubt contributed to the longevity of individual volcanoes and of the entire chain. Nevertheless, old, thick lithosphere and slow plate motion are not capable of explaining other features such as the multiple cycles of volcanism on a single island and the historic eruption of tholeiites on one of the oldest and easternmost islands.

The goal of this paper is to place constraints on a model for the origin of Gran Canaria, as well as the Canary Islands in general. In the companion paper, we present major and trace element data from mafic volcanics on Gran Canaria and evaluate the role of fractional crystallization, accumulation, and depths of melting. In this paper, we use the same data set to evaluate (1) the role of partial melting in forming the chemical diversity of the mafic volcanics, (2) the source mineralogy and composition for the different cycles of volcanism, and (3) the temporal and spatial variations in melt production rates and chemistry of the mafic volcanics. $\mathrm{Sr}-\mathrm{Nd}-\mathrm{Pb}$ isotopic compositions and $\mathrm{Rb}, \mathrm{Sr}, \mathrm{Sm}, \mathrm{Nd}, \mathrm{U}, \mathrm{Th}$, and $\mathrm{Pb}$ concentrations determined by isotope dilution for 51 of the mafic volcanics in this study and 15 evolved volcanic samples from Gran Canaria have been presented by Hoernle et al. (1991). Additional isotope and trace element data on primarily evolved lava flows and ignimbrites ( 36 in total) have been presented by Cousens et al. (1990). As the isotope data provide crucial constraints on the interpretation of major and trace element data, we summarize them below.

As illustrated on the ${ }^{87} \mathrm{Sr} /{ }^{86} \mathrm{Sr}$ vs. ${ }^{206} \mathrm{~Pb} /{ }^{204} \mathrm{~Pb}$ isotope correlation diagram (Fig. 1), the Miocene and Pliocene-Quaternary volcanics have distinct isotopic compositions. The most $\mathrm{SiO}_{2}$-undersaturated volcanics (nephelinites and basanites) have the most radiogenic $\mathrm{Pb}$ and least radiogenic $\mathrm{Sr}$ for a given age group. The $\mathrm{SiO}_{2}$-saturated mafic volcanics (alkali basalts 
and theoleiites) for both age groups have isotopic compositions which extend from the field of the undersaturated volcanics towards less radiogenic $\mathrm{Pb}$ and more radiogenic $\mathrm{Sr}$. The field for the evolved volcanics overlaps the fields for the mafic volcanics and extends towards the least radiogenic $\mathrm{Pb}$ and most radiogenic $\mathrm{Sr}$. The variation in ${ }^{143} \mathrm{Nd} /{ }^{144} \mathrm{Nd}$ for the Miocene volcanics is essentially within the analytical precision. For the Pliocene-Quaternary volcanics, the most undersaturated mafic volcanics have the most radiogenic $\mathrm{Nd}$, the saturated mafic volcanics extend to less radiogenic $\mathrm{Nd}$, and the evolved volcanics extend to the least radiogenic $\mathrm{Nd}$. The $\mathrm{Sr}, \mathrm{Nd}$, and $\mathrm{Pb}$ isotope ratios for the Pliocene-Quaternary volcanics show excellent correlations with magnesium number and other indicators of differentiation (see fig. 8 in Hoernle et al., 1991). Therefore Miocene volcanics have more

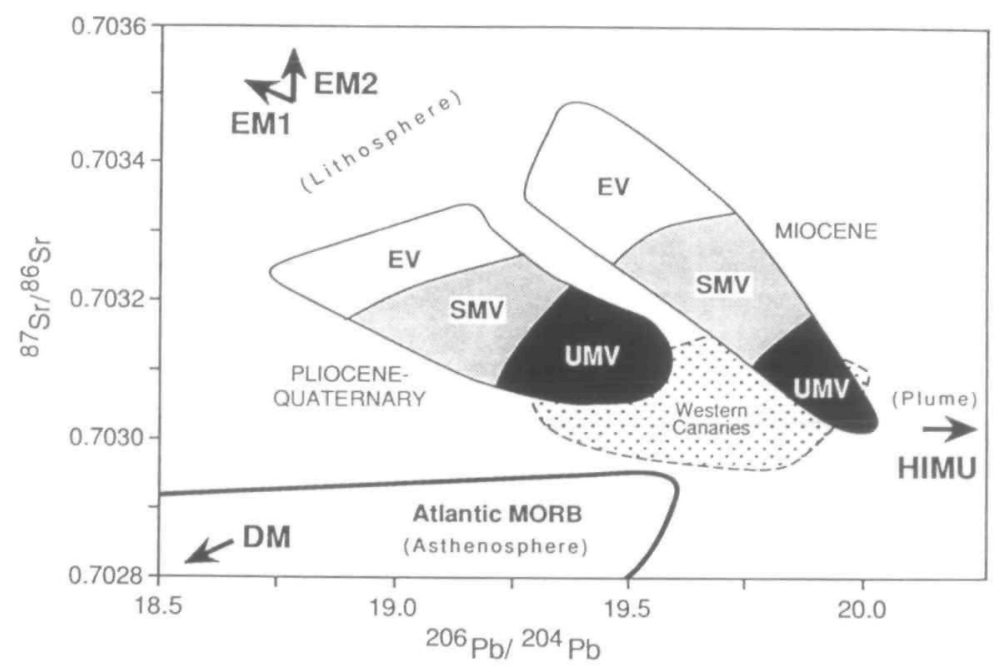

FIG. 1. ${ }^{206} \mathrm{~Pb} /{ }^{204} \mathrm{~Pb}$ vs. ${ }^{87} \mathrm{Sr} /{ }^{86} \mathrm{Sr}$ isotope correlation diagram for the Miocene and Pliocene-Quaternary Cycle volcanics on Gran Canaria (modified from Hoernle $e t$ al., 1991). The most undersaturated mafic volcanics (UMV; $\mathrm{SiO}_{2}<44$ with $m g$-number $>62$ for the Pliocene-Quaternary volcanics and $m g$-number $>50$ for the Miocene volcanics) have the most restricted isotopic compositions (black fields) for each age group. The saturated mafic volcanics ( $\mathrm{SMV} ; \mathrm{SiO}_{2}>44$ and $m g$-number $>62$ ) fall within the black and gray fields for an age group. The evolved volcanics (EV; $m g$-number $<62$ for the Pliocene-Quaternary volcanics and $m g$-number $<62$ and $\mathrm{SiO}_{2}>44$ for the Miocene volcanics) cover the entire field (black, gray, white fields) for each age group. The UMV are interpreted to have isotopic compositions [a mix of high ${ }^{238} \mathrm{U} /{ }^{204} \mathrm{~Pb}$ mantle (HIMU) and depleted mantle (DM); cf. Zindler \& Hart, 1986] similar to their sublithospheric sources. The SMV and EV are interpreted to have been derived from the same sources as the UMV from the same age group, but some have undergone minor lithospheric contamination, shifting their isotopic compositions towards enriched mantle one and two (EM1 and EM2; cf. Zindler \& Hart, 1986).

radiogenic $\mathrm{Pb}$ than the Pliocene-Quaternary volcanics. The isotopic compositions of the most undersaturated mafic volcanics for each age group are interpreted as reflecting the composition of their sub-lithospheric source material. Mixing of Miocene source (plume?) material and/or melts with more depleted mantle (upper asthenosphere?) material and/or melts could yield the isotopic composition of the Pliocene-Quaternary source. The more saturated mafic and the evolved volcanics, which are isotopically distinct from the undersaturated volcanics of the same age group, are believed to have assimilated minor amounts of lithospheric mantle with enriched isotopic compositions (Hoernle et al., 1991). 


\section{ORIGIN OF NEPHELINITES THROUGH THOLEIITES: PARTIAL MELTING}

\section{The role of major mantle phases and volatiles}

Most field and major and trace element studies conclude that increasing $\mathrm{SiO}_{2}$ concentration or saturation in the sequence nephelinite-basanite-alkali picrite (alkali basalt)-picrite (tholeiite) correlates positively with the extent of melting. As the $\mathrm{Sr}-\mathrm{Nd}-\mathrm{Pb}$ isotopic data are consistent with derivation of the nephelinite-tholeiite suites for each age group from a similar source (Hoernle et al., 1991), it is likely that the variations in major and trace elements and melt production are controlled by different degrees of melting. As observed for Hawaiian volcanoes (e.g., Clague, 1987; Frey et al., 1990), the volumes, eruption rates, and/or melt production rates (i.e., the eruption rate with a correction for volume loss as a result of crystal fractionation) on Gran Canaria correlate positively with $\mathrm{SiO}_{2}$ content (see Fig. 8 below and Hoemle \& Schmincke, this volume, fig. 2). Second, on the projection from clinopyroxene onto the base of the normative basalt tetrahedron, the fields for the mafic volcanics are shifted systematically towards the Ol-Qtz join in the sequence nephelinite to tholeiite (fig. 7 in Hoernle \& Schmincke, this volume). Third, at a given $\mathrm{MgO}$ content, the highly compatible trace elements $\mathrm{Ni}, \mathrm{Co}$, and $\mathrm{Cr}$ increase from nephelinite to picrite-tholeiite (Hoernle \& Schmincke, this volume, fig. 4 and table 1). Fourth, linear correlations, which pass through or near the origin, are formed on plots of $\mathrm{P}_{2} \mathrm{O}_{5}$ vs. Sr for all Gran Canaria mafic volcanics and on plots of $\mathrm{P}_{2} \mathrm{O}_{3}$ vs. the light rare earth elements (LREE), $\mathrm{Th}$, and $\mathrm{U}$ for the Pliocene-Quaternary mafic volcanics (and of these elements divided by $\mathrm{Al}_{2} \mathrm{O}_{3}$; see Fig. 3 below). Such relationships indicate that these elements are highly incompatible during melting in their respective sources (Sun \& Hanson, 1975a,b). Concentrations of these highly incompatible elements and ratios of highly incompatible to moderately incompatible or compatible elements-such as $\mathrm{La} / \mathrm{Yb}, \mathrm{La} / \mathrm{Sm}$, and $\mathrm{P}_{2} \mathrm{O}_{5} / \mathrm{Al}_{2} \mathrm{O}_{3}$ - decrease systematically from nephelinite to tholeiite and correlate well with $\mathrm{SiO}_{2}$ content (Fig. 2). These variations cannot be explained by fractionation of olivine and minor clinopyroxene, the major fractionating phases in the Gran Canaria mafic volcanics (Hoernle \& Schmincke, this volume). If the source composition with respect to one of these elements and the dynamics of the melting process were known, it would be possible to estimate degrees of partial melting for the different mafic volcanic types from the variation of these elements.

As has been shown by Hoernle \& Schmincke (this volume), all of the Gran Canaria mafic magmas must have originated at pressures $>3.0 \mathrm{GPa}$. The major mantle phases at pressures $>3.0 \mathrm{GPa}$ are olivine, orthopyroxene, garnet, and clinopyroxene. The projection from clinopyroxene onto the base of the mafic volcanic tetrahedron (Hoernle $\&$ Schmincke, this volume, fig. 7) provides information on the role of orthopyroxene during melting. As the mafic volcanics for both the Miocene and Pliocene-Quaternary volcanics are shifted towards the $\mathrm{Ol}+\mathrm{Qtz}$ join in the sequence nephelinite to tholeiite-picrite, instead of towards the olivine apex, both olivine and orthopyroxene must be residual phases in the sources of all the mafic melts (Falloon \& Green, 1988; Falloon et al., 1988). The slightly increasing $\mathrm{Al}_{2} \mathrm{O}_{3}$ and $Y$ contents from nephelinite to tholeiite and overlapping heavy REE (HREE) patterns (Hoernle \& Schmincke, this volume, figs. 4 and 5) are consistent with residual garnet in the source after extraction of all Gran Canaria melts (Schmincke, 1982). Little garnet or clinopyroxene, however, remains in the residue at the highest degrees of melting, as the $\mathrm{CaO} / \mathrm{Al}_{2} \mathrm{O}_{3}$ ratio approaches the chondritic value in both the Miocene and Pliocene tholeiites.

Different degrees of partial melting under volatile-absent conditions and variation in pressure for liquids in equilibrium with a garnet lherzolite between 2.8 and 4.0 GPa, however, 

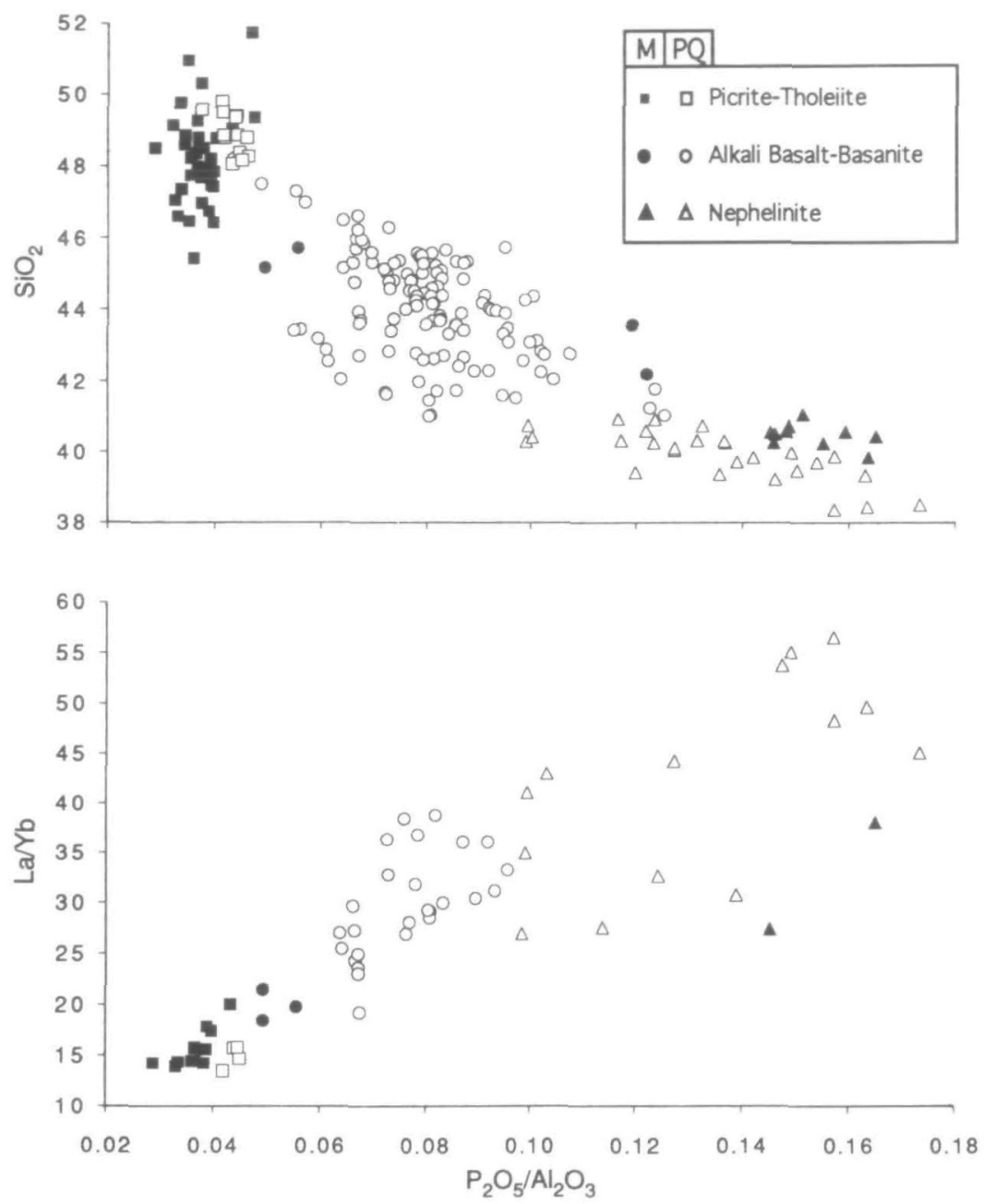

FIG. 2. Plot of $\mathrm{P}_{2} \mathrm{O}_{5} / \mathrm{Al}_{2} \mathrm{O}_{3}$ ratio vs. $\mathrm{SiO}_{2}$ and $\mathrm{La} / \mathrm{Yb}$ for the Gran Canaria Miocene (M) and Pliocene-Quaternary (PQ) mafic volcanics. Fractional crystallization will not significantly change the $\mathrm{P}_{2} \mathrm{O}_{5} / \mathrm{Al}_{2} \mathrm{O}_{3}$ ratio in the mafic volcanics. As long as garnet is residual in the source assemblage, the $\mathrm{P}_{2} \mathrm{O}_{5} / \mathrm{Al}_{2} \mathrm{O}_{3}$ ratio (or the ratio of any incompatible element to $\mathrm{Al}_{2} \mathrm{O}_{3}$ ) will decrease with increasing degrees of partial melting. The excellent negative correlation of $\mathrm{P}_{2} \mathrm{O}_{3} / \mathrm{Al}_{2} \mathrm{O}_{3}$ vs. $\mathrm{SiO}_{2}$ and positive correlation of $\mathrm{P}_{2} \mathrm{O}_{3} / \mathrm{Al}_{2} \mathrm{O}_{3}$ vs. $\mathrm{La} / \mathrm{Yb}$ are also consistent with increasing degrees of partial melting from nephelinite to tholeiite. Data sources are Schmincke (1982, 1987), Crisp (1984), Hoernle, (1987), Cousens (1990), Cousens et al. (1990), Hoernle \& Schmincke (this volume), and H.-U.

Schmincke \& P. T. Robinson, unpub. data.

cannot explain the large range in $\mathrm{SiO}_{2}$ concentration, from 38 to $52 \mathrm{wt} . \%$, of the Gran Canaria mafic volcanics (Adam, 1988). The lowest $\mathrm{SiO}_{2}$ content that has been obtained in recent high-pressure melting experiments to $3.5 \mathrm{GPa}$ is $\sim 46$ wt. \% (Jacques \& Green, 1980; Takahashi \& Kushiro, 1983; Falloon \& Green, 1988; Falloon et al., 1988). It has been proposed, however, that melting under volatile-saturated conditions with high $\mathrm{H}_{2} \mathrm{O}$ and $\mathrm{CO}_{2}$ contents and a high $\mathrm{CO}_{2} / \mathrm{H}_{2} \mathrm{O}$ ratio could generate highly undersaturated liquids (Brey \& Green, 1977; Brey, 1978; Le Bas, 1978). The association of carbonatites with isotopically similar nephelinites, ijolites, and basanites on the neighboring island of Fuerteventura (Hoernle \& Tilton, 1991) supports the derivation of the undersaturated mafic volcanics from sources rich in C-bearing species. Increasing $\mathrm{C}, \mathrm{CO}_{2}$, and/or $\mathrm{CO}_{3}$ saturation in the sequence 
tholeiite to nephelinite could also explain why the field formed by the calculated primary melts on the base of the basalt tetrahedron is oblique to the high-pressure cotectics with the nephelinitic end shifted towards the olivine apex (Hoernle \& Schmincke, this volume, fig. 7).

In conclusion, the Miocene and Pliocene-Quaternary nephelinite through picrite-tholeiite sequences show the following systematic variations: the melt production rates and the highly compatible element concentrations increase, whereas the highly incompatible elements and the ratios of more incompatible to less incompatible elements decrease. Taken together with the isotope data, these observations strongly favor derivation of the nephelinite to picrite-tholeiite sequences on Gran Canaria through increasing degrees of partial melting.

\section{The role of accessory phases}

\section{Incompatible element concentrations}

$\mathrm{P}_{2} \mathrm{O}_{5}, \mathrm{~K}_{2} \mathrm{O}, \mathrm{TiO}_{2}, \mathrm{Sr}, \mathrm{Rb}, \mathrm{Ba}, \mathrm{Nb}, \mathrm{Ta}, \mathrm{Zr}, \mathrm{Hf}, \mathrm{LREE}, \mathrm{Th}, \mathrm{U}$, and $\mathrm{Pb}$ are highly incompatible in most mafic volcanic fractionating assemblages and in the major peridotitic minerals (olivine, pyroxene, and garnet). Although variations in these elements could reflect random source heterogeneity or the effects of wall-rock interaction during ascent, the similar behavior of many of these elements suggests that they may be controlled by the presence of

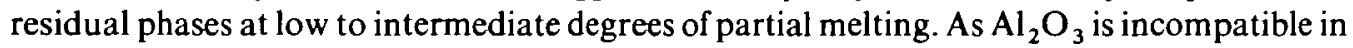
olivine, and as clinopyroxene fractionation is minor in the Gran Canaria mafic volcanics, the ratio of an element incompatible in these fractionating phases to $\mathrm{Al}_{2} \mathrm{O}_{3}$ should be similar to the ratio in the parental melt. The ratio of an element $(X)$ incompatible during melting to $\mathrm{Al}_{2} \mathrm{O}_{3}$ should decrease systematically with increasing degree of partial melting, as is the case with $\mathrm{P}_{2} \mathrm{O}_{5} / \mathrm{Al}_{2} \mathrm{O}_{3}$ (Fig. 2), as $\mathrm{Al}_{2} \mathrm{O}_{3}$ is buffered by residual garnet. When two completely incompatible elements (divided by $\mathrm{Al}_{2} \mathrm{O}_{3}$ ), are plotted against each other, the trend will be linear and pass through (or near) the origin, as is observed for $\mathrm{P}_{2} \mathrm{O}_{5} / \mathrm{Al}_{2} \mathrm{O}_{3}$ vs. Sr $/ \mathrm{Al}_{2} \mathrm{O}_{3}$ (Fig. 3). If the trend on a $\mathrm{P}_{2} \mathrm{O}_{5} / \mathrm{Al}_{2} \mathrm{O}_{3}$ vs. $X / \mathrm{Al}_{2} \mathrm{O}_{3}$ plot is not linear (i.e., is kinked) or does not pass through the origin, an accessory phase in the residuum may be buffering element $X$ at the lower degrees of melting. The non-linear or kinked trends on these plots (Fig. 3) cannot be easily explained by mixing.

The mantle mineral most likely to retain $\mathrm{P}_{2} \mathrm{O}_{5}$ is apatite (Schmincke \& Flower, 1974; Sun \& Hanson, 1975a,b; Green, 1981; Greenough, 1988). Apatite has large partition coefficients $\left(K_{\mathrm{d}}\right)$ for $\mathrm{Sr}$ and the REE and may control the abundances of these elements. The systematic increase in $\mathrm{P}_{2} \mathrm{O}_{5} / \mathrm{Al}_{2} \mathrm{O}_{3}$ and $\mathrm{Sr} / \mathrm{Al}_{2} \mathrm{O}_{3}$ for all the mafic volcanics and in LREE and LREE $/ \mathrm{Al}_{2} \mathrm{O}_{3}$ for the Pliocene-Quaternary mafic volcanics with decreasing $\mathrm{SiO}_{2}$ content (Figs. 2 and 3 ) are inconsistent with residual apatite in the source(s) of the Canary volcanics. Furthermore, according to high-pressure $(2.5 \mathrm{GPa})$ experimental results, the solubility of $\mathrm{P}_{2} \mathrm{O}_{3}$ in a basic melt with $50 \% \mathrm{SiO}_{2}$ is $3-4 \mathrm{wt} . \%$, and it increases with decreasing $\mathrm{SiO}_{2}$ saturation of the melt (Watson, 1980). As all of the Canary mafic volcanics have $<2.5 \mathrm{wt} . \%$ $\mathrm{P}_{2} \mathrm{O}_{5}$, they are all undersaturated in $\mathrm{P}_{2} \mathrm{O}_{5}$, which also suggests that apatite is not a residual phase.

For the Pliocene-Quaternary mafic volcanics, the abundances of $\mathrm{K}_{2} \mathrm{O}, \mathrm{Rb}, \mathrm{Ba}, \mathrm{TiO}_{2}, \mathrm{Nb}$, $\mathrm{Ta}, \mathrm{Zr}$, and $\mathrm{Hf}$ (and these elements divided by $\mathrm{Al}_{2} \mathrm{O}_{3}$ ) increase or remain roughly constant in the nephelinites and some basanites and then decrease with decreasing $\mathrm{P}_{2} \mathrm{O}_{5} / \mathrm{Al}_{2} \mathrm{O}_{3}$ (e.g., Fig. 3). The $\mathrm{Hf} / \mathrm{Sm}$ and $\mathrm{Ti} / \mathrm{Eu}$ ratios increase with decreasing $\mathrm{P}_{2} \mathrm{O}_{5} / \mathrm{Al}_{2} \mathrm{O}_{3}$ for the nephelinites, basanites, and some alkali basalts, but are constant in most alkali basalts and the tholeiites. A residual K-phase and an Fe-Ti oxide phase in the nephelinites and basanites could account for these variations (Schmincke \& Flower, 1974; Schmincke, 1982; Greenough, 1988; Marcelot et al., 1989; O'Reilly et al., 1991). Lower Ba/Sr and K/Nb 


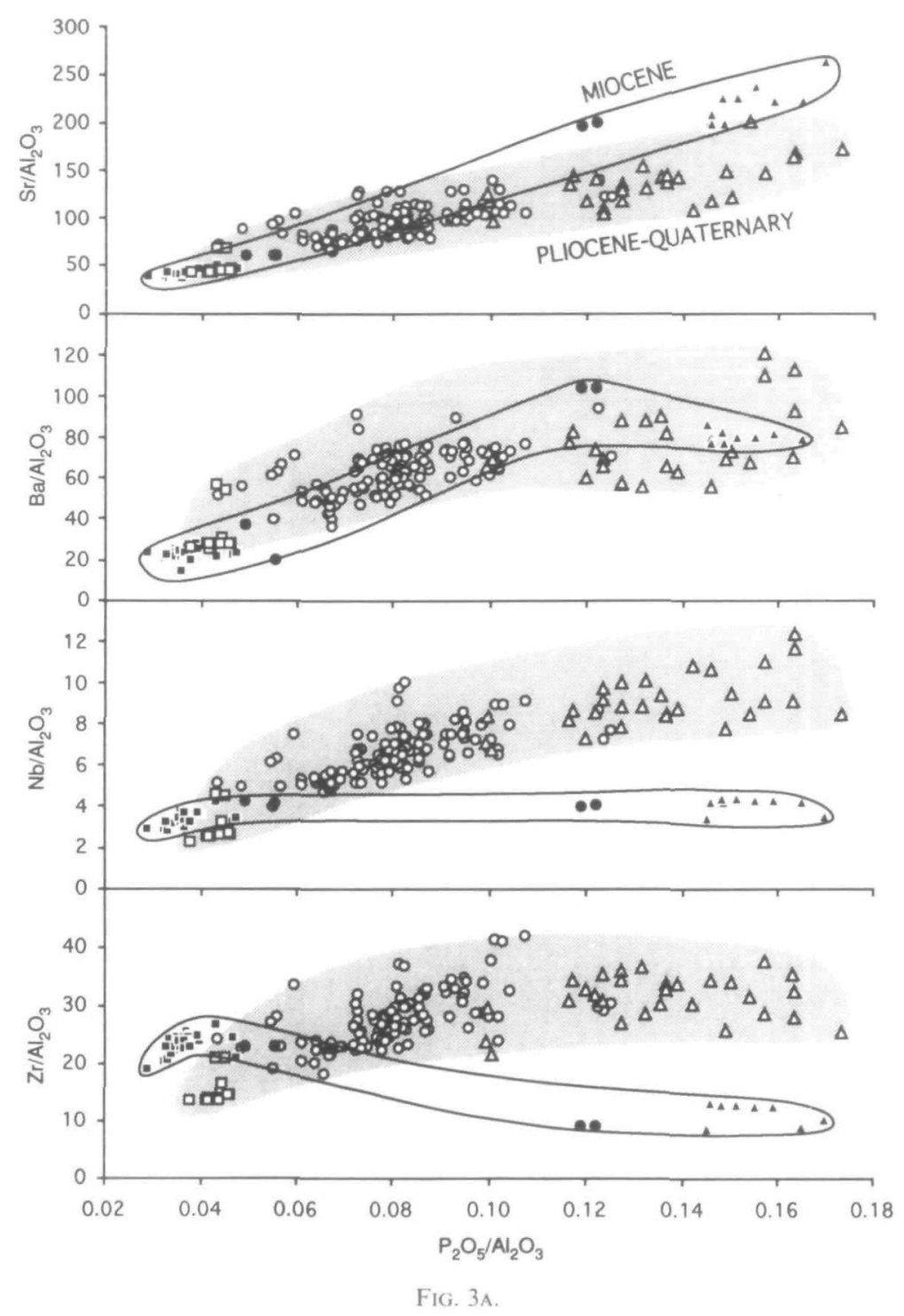

(Fig. 4a) ratios in the nephelinites and basanites than in the alkali basalts and tholeiites argue for generation of these magmas in the presence of residual phlogopite, instead of amphibole (Clague \& Frey, 1982; Hawkesworth et al., 1990), consistent with the major element evidence that these mafic volcanics were formed at pressures in excess of $3.0 \mathrm{GPa}$ (Hoernle \& Schmincke, this volume). Titanite, rutile, and perovskite are unlikely residual $\mathrm{Fe}-\mathrm{Ti}$ oxide phases, as the mafic volcanics originated at pressures $>3.0 \mathrm{GPa}$, and the abundances of $\mathrm{Sr}$ and the LREE are not affected by the residual phases (Irving, 1978; Hanson, 1980; Green, 1981; Clague \& Frey, 1982; Jones \& Wyllie, 1984; Greenough, 1988). Therefore the most likely $\mathrm{Fe}$-Ti oxide phase is ilmenite.

The trends of $\left(\mathrm{TiO}_{2}, \mathrm{Rb}, \mathrm{K}_{2} \mathrm{O}, \mathrm{Zr}, \mathrm{Hr}, \mathrm{Nb}, \mathrm{Ta}\right) / \mathrm{Al}_{2} \mathrm{O}_{3}$ vs. $\mathrm{P}_{2} \mathrm{O}_{5} / \mathrm{Al}_{2} \mathrm{O}_{3}$ for the Miocene mafic volcanics increase or remain constant from the nephelinites to alkali basalts (and possibly some tholeiites) and then decrease (e.g., Fig. 3), suggesting that phlogopite and 


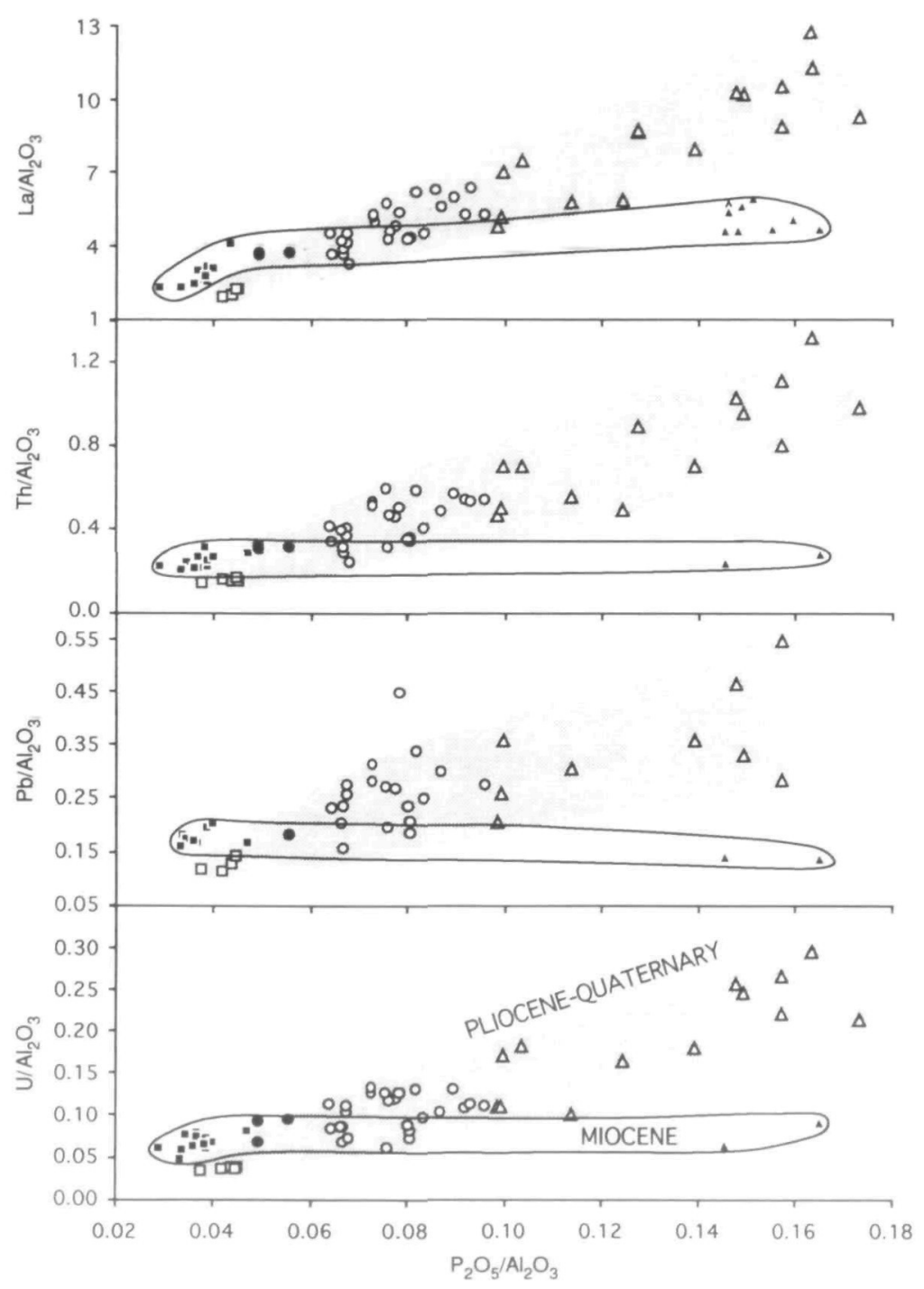

FIG. 3B. Representative plots of $\mathrm{P}_{2} \mathrm{O}_{5} / \mathrm{Al}_{2} \mathrm{O}_{3}$ ratio vs. ( $\left.\mathrm{Sr}, \mathrm{Ba}, \mathrm{Nb}, \mathrm{Zr}, \mathrm{La}, \mathrm{Th}, \mathrm{Pb}, \mathrm{U}\right) / \mathrm{Al}_{2} \mathrm{O}_{3}$. The non-linear trends, which do not pass through the origin, suggest the survival of accessory phases, such as phlogopite, ilmenite, sulfides, and possibly zircon, in the residuum of the $\mathrm{SiO}_{2}$-undersaturated mafic volcanics. Symbols and references include those in Fig. 2 and Hoernle et al. (1991).

possibly ilmenite were residual to higher degrees of melting in the Miocene source(s). In contrast to the well-defined positive correlations formed on plots of (Th, U, LREE, and to a lesser extent $\mathrm{Pb}) / \mathrm{Al}_{2} \mathrm{O}_{3}$ vs. $\mathrm{P}_{2} \mathrm{O}_{5} / \mathrm{Al}_{2} \mathrm{O}_{3}$ by the Pliocene-Quaternary mafic volcanics, the trends for the Miocene mafic volcanics increase or remain constant from the nephelinites to alkali basalts and some tholeiites. Zircon could control the variations in these elements, as well as some of the variation in $\mathrm{Zr}, \mathrm{Hf}, \mathrm{Nb}$, and $\mathrm{Ta}$, without affecting the concentrations of $\mathrm{P}_{2} \mathrm{O}_{3}$ or Sr (Green, 1981; Irving \& Frey, 1984; Fujimaki, 1986; Greenough, 1988). Zircon also has very high partition coefficients for the HREE elements (Hanson, 1980; Green, 1981; Irving \& Frey, 1984; Fujimaki, 1986); but because of its low abundance, especially relative to garnet, it probably would only have a minor effect on the HREE concentration in the melt 

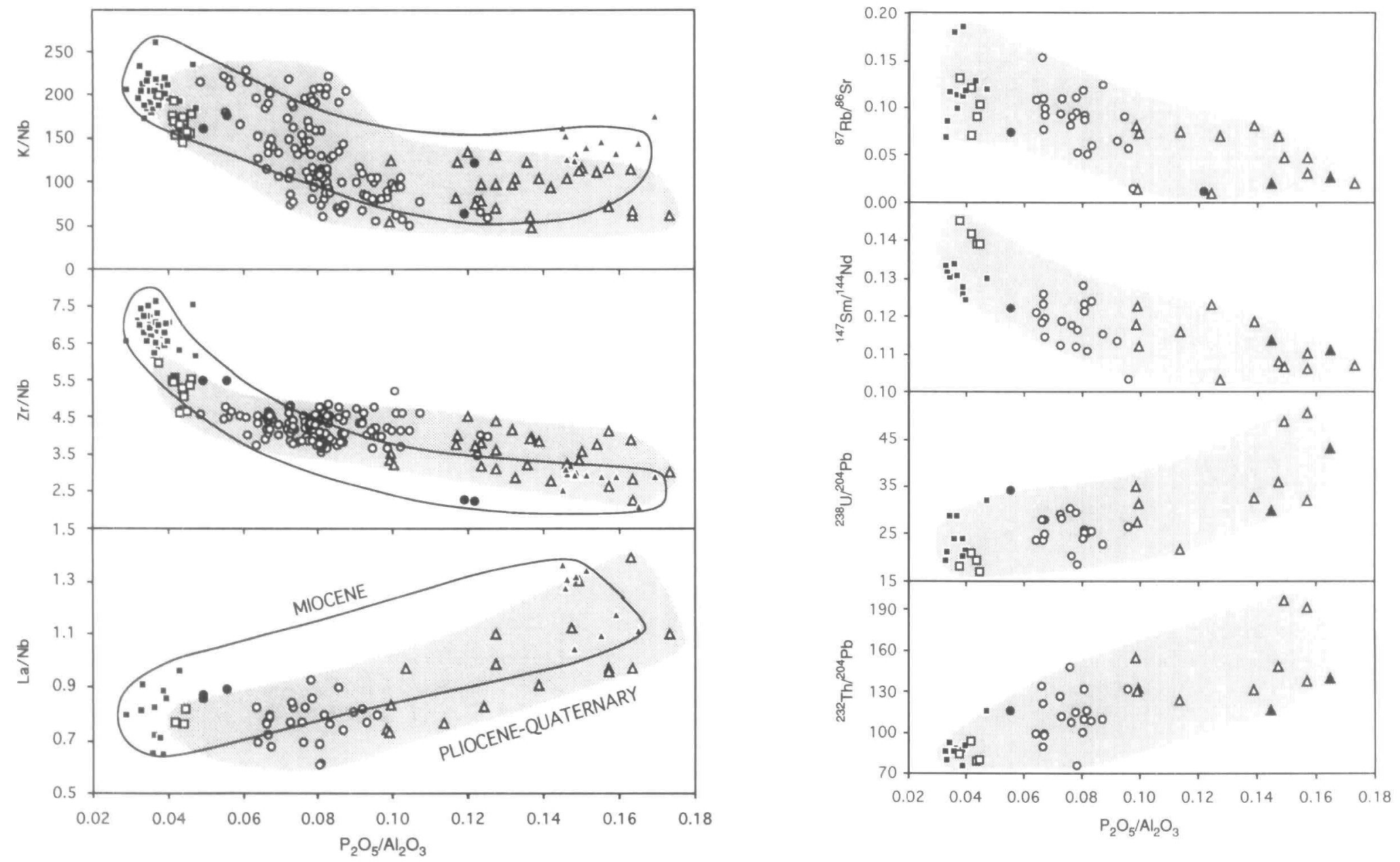

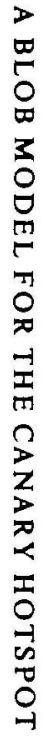

Fig. 4. The good correlations between $\mathrm{P}_{2} \mathrm{O}_{5} / \mathrm{Al}_{2} \mathrm{O}_{3}$ ratio and (a) $\mathrm{K} / \mathrm{Nb}, \mathrm{Zr} / \mathrm{Nb}$, and $\mathrm{La} / \mathrm{Nb}$ (references same as in $\mathrm{Fig}$. 2) and (b) parent-daughter ratios for the $\mathrm{Sr}, \mathrm{Nd}$, and $\mathrm{Pb}$ isotope systems [isotope dilution data from Hoernle et al. (1991)] suggest that partial melting can fractionate these incompatible element ratios. Symbols are the same as in Fig. 2 . 
(Hanson, 1980). Although not commonly invoked as a residual phase in the mantle, zircon is associated with high-pressure phases in kimberlites (Meyer \& Tsai, 1976; Raber \& Haggerty, 1979 ) and may occur as minute inclusions in mantle phlogopite (Greenough, 1988). Zircon megacrysts occur in highly undersaturated mafic volcanics from a variety of localities including Australia, southeast Asia, Algeria, France, Scotland, and possibly Nigeria (Irving \& Frey, 1984).

In summary, the variations in incompatible element abundances can be explained by the presence of accessory phases in the Miocene and Pliocene-Quaternary sources. Phlogopite, an $\mathrm{Fe}-\mathrm{Ti}$ oxide such as ilmenite, apatite, and a carbonate phase were probably present in both sources. Phlogopite and ilmenite were residual phases during the generation of (1) the Pliocene-Quaternary nephelinites, basanites, and some alkali basalts and (2) the Miocene nephelinites, basanites, alkali basalts, and some tholeiites. To explain the low concentrations of the LREE, $\mathrm{U}, \mathrm{Th}$, and $\mathrm{Pb}$, and the high $\mathrm{Nb} / \mathrm{Zr}$ ratios, an additional accessory phase, possibly zircon, is also required in the residuum of the Miocene nephelinites through some tholeiites. The survival of accessory phases to higher degrees of partial melting in the Miocene source suggests that the modal percentages of accessory phases may have been greater in the Miocene than in the Pliocene-Quaternary source(s).

\section{Incompatible element ratios}

Ratios of elements highly incompatible in major mantle phases or of incompatible elements with similar bulk distribution coefficients are commonly interpreted to be independent of (or not significantly affected by) partial melting and crystallization processes in basalts. Therefore these ratios are believed to reflect source characteristics, similar to radiogenic isotope ratios of $\mathrm{Sr}, \mathrm{Nd}$, and $\mathrm{Pb}$ (e.g., Jochum et al., 1983; Hofmann et al., 1986; Sun \& McDonough, 1989; Weaver, 1991). Correlations between isotope and highly incompatible trace element ratios for various ocean island basalt (OIB) suites (e.g., Palacz \& Saunders, 1986; Weaver et al., 1986) and OIB end-members (HIMU, EM1, and EM2) (Sun \& McDonough, 1989; Weaver, 1991) are consistent with coupling between isotope and incompatible trace element ratios in at least some cases. The Gran Canaria mafic volcanics exhibit extreme variability in incompatible trace element ratios, such as $\mathrm{Nb} / \mathrm{U}, \mathrm{Pb} / \mathrm{Ce}, \mathrm{K} / \mathrm{U}$, $\mathrm{Nb} / \mathrm{Pb}, \mathrm{Ba} / \mathrm{Rb}, \mathrm{Zr} / \mathrm{Hf}, \mathrm{La} / \mathrm{Nb}, \mathrm{Ba} / \mathrm{Nb}, \mathrm{Ba} / \mathrm{Th}, \mathrm{Rb} / \mathrm{Nb}, \mathrm{K} / \mathrm{Nb}, \mathrm{Zr} / \mathrm{Nb}, \mathrm{Th} / \mathrm{Nb}, \mathrm{Th} / \mathrm{La}$, and $\mathrm{Ba} / \mathrm{La}$ (Table 1 and Figs. 4-6). Surprisingly, the range in many of these ratios for Gran Canaria, a single island, is similar to or larger than the range reported for most other OIB (Table 1)! The extreme range in incompatible element ratios is even more surprising considering the relatively limited range in $\mathrm{Sr}, \mathrm{Nd}$, and $\mathrm{Pb}$ isotopes ratios for Gran Canaria compared with the range reported for OIB (Hoernle et al., 1991). Isotope ratios of ${ }^{87} \mathrm{Sr} /{ }^{86} \mathrm{Sr}$, ${ }^{143} \mathrm{Nd} /{ }^{144} \mathrm{Nd},{ }^{206} \mathrm{~Pb} /{ }^{204} \mathrm{~Pb}$, and ${ }^{208} \mathrm{~Pb} /{ }^{204} \mathrm{~Pb}$ correlate well with each other for both the Miocene and the Pliocene-Quaternary Cycles of volcanism, consistent with two-component mixing for each cycle of volcanism as is illustrated in Fig. 1. Can the range in incompatible element ratios for each age group also be explained by simple two-component mixing?

Below we present several arguments against coupling of the isotope and incompatible trace element ratios, which instead suggest fractionation of the incompatible element ratios by partial melting. First, the incompatible trace element ratios mentioned above either do not correlate with or only form very poor correlations with isotope ratios. Whereas isotope ratios for an age group show excellent correlations with degree of differentiation (e.g., see fig. 8 in Hoernle et al., 1991), the above incompatible element ratios generally form good (in many cases excellent) correlations with $\mathrm{P}_{2} \mathrm{O}_{5} / \mathrm{Al}_{2} \mathrm{O}_{3}, \mathrm{La} / \mathrm{Yb}, \mathrm{SiO}_{2}$ or incompatible trace element concentrations and melt production rate (Figs. 4-6 and 8). Second, simple twocomponent mixing requires that the data form a linear trend on diagrams of $1 / X$ vs. $Y / X$ 
TABLE 1

Incompatible trace element ratios in Gran Canaria mafic volcanics, Honolulu volcanics, OIB end-members, and major chemical reservoirs

\begin{tabular}{|c|c|c|c|c|c|c|c|c|c|c|c|c|}
\hline & $\mathrm{Zr} / \mathrm{Nb}$ & $L a / N b$ & $\mathrm{Ba} / \mathrm{Nb}$ & $B a / T h$ & $K / N b$ & $N b / T h$ & $L a / T h$ & $\mathrm{Ba} / \mathrm{La}$ & $\mathrm{Nb} / \mathrm{Pb}$ & $\mathrm{Pb} / \mathrm{Ce}$ & $N b / U$ & $K / U$ \\
\hline $\begin{array}{l}\text { Miocene } \\
\text { Range } \\
\text { Average } \\
\text { From NEPH to TH }\end{array}$ & $\begin{array}{c}2 \cdot 1-9 \cdot 2 \\
5 \cdot 9 \\
\text { increase }\end{array}$ & $\begin{array}{c}0.65-1 \cdot 36 \\
0.96 \\
\text { decrease }\end{array}$ & $\begin{array}{c}3 \cdot 7-26 \cdot 0 \\
9 \cdot 8 \\
\text { decrease }\end{array}$ & $\begin{array}{c}62-351 \\
117 \\
\text { decrease }\end{array}$ & $\begin{array}{c}64-260 \\
187 \\
\text { increase }\end{array}$ & $\begin{array}{c}11 \cdot 4-14 \cdot 6 \\
14-0 \\
\text { no trend }\end{array}$ & $\begin{array}{c}8.9-18.7 \\
11.9 \\
\text { decrease }\end{array}$ & $\begin{array}{l}5 \cdot 2-18 \cdot 8 \\
110 \\
\text { decrease }\end{array}$ & $\begin{array}{l}14 \cdot 8-30-2 \\
20-4 \\
\text { decrease }\end{array}$ & $\begin{array}{c}0-015-0-035 \\
0-026 \\
\text { increase }\end{array}$ & $\begin{array}{c}40-65 \\
51 \\
\text { no trend }\end{array}$ & $\begin{array}{c}6700-12800 \\
9800 \\
\text { increase }\end{array}$ \\
\hline $\begin{array}{l}\text { Plio.-Quaternary } \\
\text { Range } \\
\text { Average } \\
\text { From NEPH to TH }\end{array}$ & $\begin{array}{c}2 \cdot 3-5 \cdot 9 \\
4 \cdot 2 \\
\text { increase }\end{array}$ & $\begin{array}{c}0-60-1 \cdot 40 \\
0-85 \\
\text { decrease }\end{array}$ & $\begin{array}{c}5 \cdot 2-16 \cdot 4 \\
9 \cdot 6 \\
\text { no trend }\end{array}$ & $\begin{array}{c}70-182 \\
130 \\
\text { increase }\end{array}$ & $\begin{array}{c}48-228 \\
126 \\
\text { increase }\end{array}$ & $\begin{array}{l}8 \cdot 1-20-0 \\
13 \cdot 7 \\
\text { increase }\end{array}$ & $\begin{array}{l}8 \cdot 5-14 \cdot 7 \\
11 \cdot 0 \\
\text { increase }\end{array}$ & $\begin{array}{c}5 \cdot 5-15 \cdot 8 \\
11 \cdot 4 \\
\text { increase }\end{array}$ & $\begin{array}{l}18 \cdot 9-32 \cdot 1 \\
24 \cdot 2 \\
\text { no trend }\end{array}$ & $\begin{array}{c}0-015-0-031 \\
0-025 \\
\text { increase }\end{array}$ & $\begin{array}{c}32-81 \\
57 \\
\text { increase }\end{array}$ & $\begin{array}{l}2400-13900 \\
7200 \\
\text { increase }\end{array}$ \\
\hline $\begin{array}{l}\text { Honolulu } \\
\text { Range } \\
\text { Average } \\
\text { From NEPH to AB }\end{array}$ & $\begin{array}{c}3 \cdot 2-4 \cdot 6 \\
3 \cdot 7 \\
\text { increase }\end{array}$ & $\begin{array}{c}0-8-2 \cdot 1 \\
1 \cdot 4 \\
\text { decrease }\end{array}$ & $\begin{array}{c}11 \cdot 6-20.9 \\
17.5 \\
\text { decrease }\end{array}$ & $\begin{array}{c}84-200 \\
131 \\
\text { increase }\end{array}$ & $\begin{array}{c}183-219 \\
204 \\
\text { no trend }\end{array}$ & $\begin{array}{c}4 \cdot 9-13 \cdot 3 \\
8 \cdot 1 \\
\text { increase }\end{array}$ & $\begin{array}{c}8 \cdot 3-12 \cdot 5 \\
10-2 \\
\text { increase }\end{array}$ & $\begin{array}{c}9 \cdot 0-16 \cdot 8 \\
12 \cdot 5 \\
\text { increase }\end{array}$ & $\begin{array}{c}4 \cdot 7-12 \cdot 7 \\
8 \cdot 3 \\
\text { decrease }\end{array}$ & $\begin{array}{c}0-026-0-091 \\
0-056 \\
\text { increase }\end{array}$ & & \\
\hline $\begin{array}{l}\text { HIMU } \\
\text { EM } \\
\text { N-MORB } \\
\text { Continental crust } \\
\text { Primitive mantle }\end{array}$ & $\begin{array}{l}2 \cdot 7-5 \cdot 5 \\
3 \cdot 5-13 \cdot 1 \\
30 \\
16 \cdot 2 \\
14 \cdot 8\end{array}$ & $\begin{array}{c}0.64-0.82 \\
0.78-1.6 \\
1.07 \\
2.2 \\
0.94\end{array}$ & $\begin{array}{c}4 \cdot 7-6 \cdot 9 \\
6 \cdot 4-23 \cdot 4 \\
4 \cdot 3 \\
54 \\
9 \cdot 0\end{array}$ & $\begin{array}{c}39-85 \\
57-204 \\
60 \\
124 \\
77\end{array}$ & $\begin{array}{c}66-187 \\
170-523 \\
296 \\
1341 \\
323\end{array}$ & $\begin{array}{l}8 \cdot 1-14 \cdot 1 \\
6 \cdot 0-11 \cdot 5 \\
20 \\
2 \cdot 3 \\
8 \cdot 6\end{array}$ & $\begin{array}{c}1 \cdot 0-6 \cdot 1 \\
5 \cdot 5-11 \cdot 2 \\
150 \\
4 \cdot 9 \\
8 \cdot 0\end{array}$ & $\begin{array}{c}6 \cdot 2-9 \cdot 3 \\
7 \cdot 3-19 \cdot 1 \\
4 \cdot 0 \\
25-0 \\
9 \cdot 6\end{array}$ & $\begin{array}{c}18-23 \\
8 \cdot 3-15 \cdot 9 \\
7 \cdot 5\end{array}$ & $\begin{array}{c}0-026-0-034 \\
0-029-0-069 \\
0-04 \\
0-25 \\
0-11\end{array}$ & $\begin{array}{c}43-52 \\
36-56 \\
47 \\
10 \\
30\end{array}$ & $\begin{array}{l}6000-8000 \\
6000-18000 \\
12700 \\
12700 \\
12700\end{array}$ \\
\hline $\begin{array}{l}\text { OIB range } \\
\text { Gran Canaria range }\end{array}$ & $\begin{array}{l}2 \cdot 7-13 \cdot 1 \\
2 \cdot 1-9 \cdot 2\end{array}$ & $\begin{array}{l}0-64-1 \cdot 60 \\
0-60-1 \cdot 40\end{array}$ & $\begin{array}{l}4 \cdot 7-23 \cdot 4 \\
3 \cdot 7-26 \cdot 0\end{array}$ & $\begin{array}{l}39-204 \\
62-351\end{array}$ & $\begin{array}{l}66-523 \\
48-260\end{array}$ & $\begin{array}{l}6 \cdot 0-14 \cdot 1 \\
8 \cdot 1-20 \cdot 0\end{array}$ & $\begin{array}{l}1 \cdot 0-11 \cdot 2 \\
8 \cdot 5-18 \cdot 7\end{array}$ & $\begin{array}{l}6 \cdot 2-19 \cdot 1 \\
5 \cdot 2-18 \cdot 8\end{array}$ & $\begin{array}{c}8 \cdot 3-23 \\
14 \cdot 8-32 \cdot 1\end{array}$ & $\begin{array}{l}0-026-0-069 \\
0-015-0-035\end{array}$ & $\begin{array}{l}36-56 \\
32-81\end{array}$ & $\begin{array}{l}6000-18000 \\
2400-13900\end{array}$ \\
\hline
\end{tabular}

It is indicated if incompatible element ratios increase, decrease or show no trend in the sequence nephelinite (NEPH) to tholeiite (TH) for the Miocene and Pliocene-Quaternary volcanics (Gran Canaria), and in the sequence nephelinite to alkali basalt (AB) for the Honolulu volcanics (Oahu, Hawaiian Islands). (Note the extreme range in incompatible element ratios for both the Gran Canaria and Honolulu mafic volcanics, which in most cases show a similar or larger range than those reported from most other OIB.) Data sources: Miocene and Pliocene-Quaternary volcanics (Hoernle et al., 1991; Hoernle \& Schmincke, this volume); Honolulu volcanics (Clague \& Frey, 1982); HIMU islands, EM islands, N-MORB, continental crust, and primitive mantle (Jochum et al., 1983; Hofmann et al., 1986; Sun \& McDonough, 1989; Weaver, 1991; and references therein). 

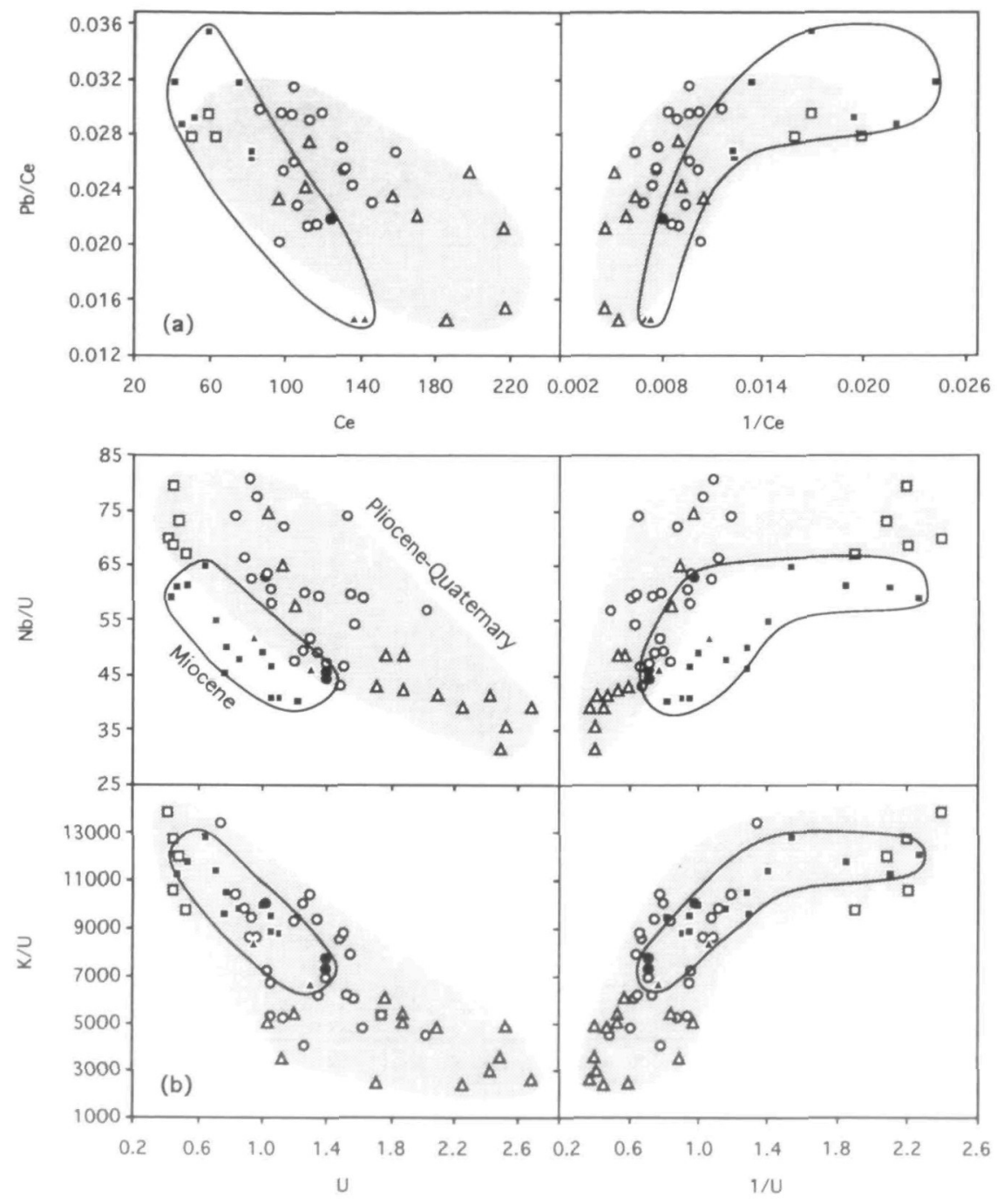

FiG. 5. (a) and (b).

(where $X$ and $Y$ are the concentrations of incompatible elements). As is illustrated in Fig. 5, the data do not form linear trends on these diagrams. Instead, the data form linear trends on $X$ vs. $Y / X$ diagrams and appear to form hyperbolic trends on $1 / X$ vs. $Y / X$ diagrams. Such trends have been interpreted as evidence of batch partial melting with constant bulk distribution coefficients (e.g., Clague \& Frey, 1982; Hanson, 1990). Third, it has been shown that the ratios of $\mathrm{La} / \mathrm{Nb}$ and $\mathrm{Ba} / \mathrm{Nb}$ correlate remarkably well with isotopic composition, especially ${ }^{87} \mathrm{Sr} /{ }^{86} \mathrm{Sr}$, for many ocean islands (Weaver et al., 1986; Sun \& McDonough, 1989). Below we show that $\mathrm{La} / \mathrm{Nb}$ and $\mathrm{Ba} / \mathrm{Nb}$ ratios lead to the opposite conclusion from the isotope data, unless partial melting is invoked to explain the difference in these incompatible element ratios between small-degree (nephelinite and basanite) and large-degree (tholeiite and alkali basalt) melts.

Mafic volcanics from islands with HIMU-like isotopic characteristics (radiogenic $\mathrm{Pb}$ ) (e.g., St. Helena, Mangaia, and Tubuaii) have low $\mathrm{La} / \mathrm{Nb}(<0-8)$ and $\mathrm{Ba} / \mathrm{Nb}(<7)$ ratios, 


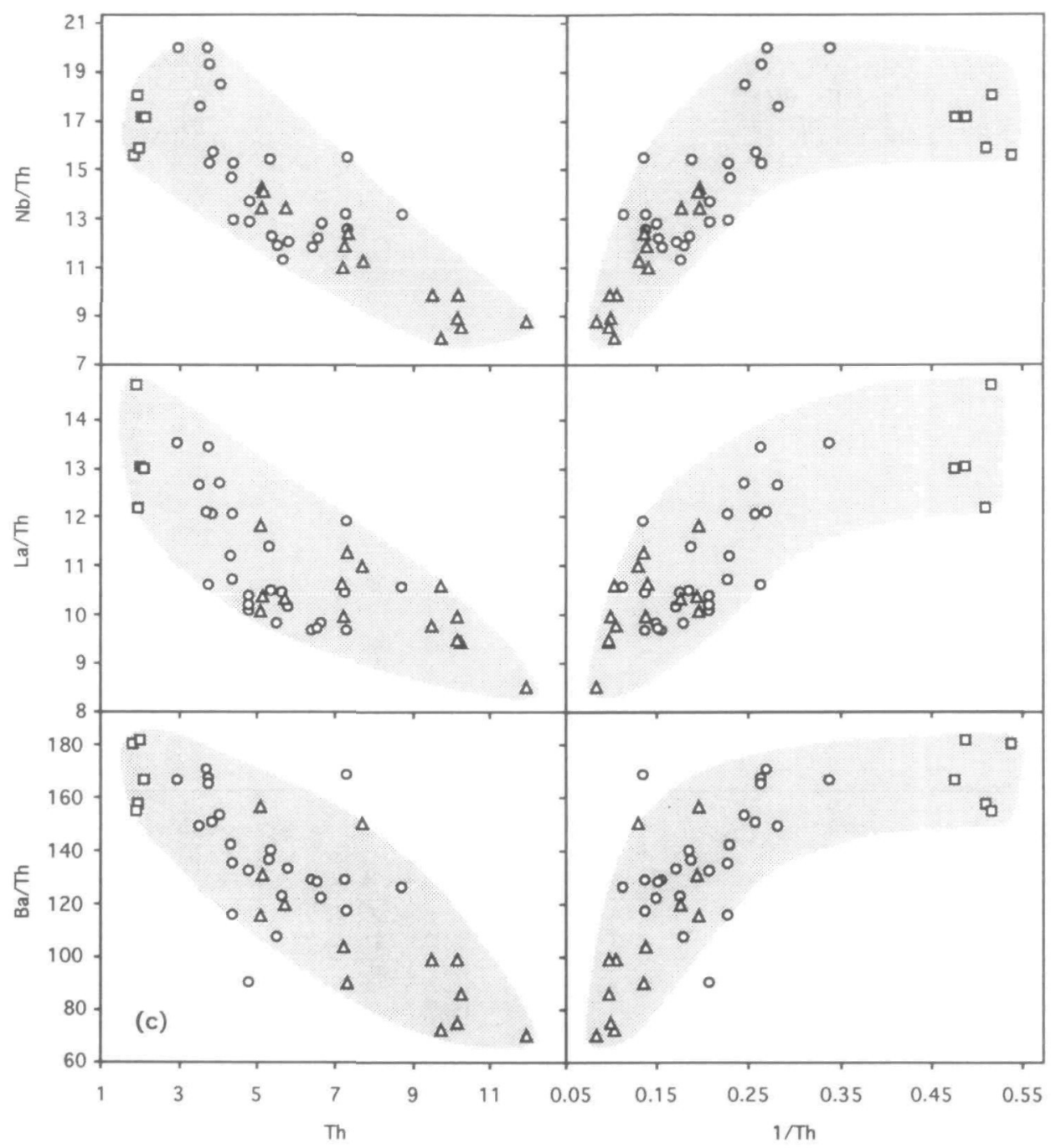

FIG. 5. (c) Companion plots of $X$ vs. $Y / X$ and $1 / X$ vs. $Y / X$ for highly incompatible elements $(X$ and $Y$ ) in Gran Canaria mafic volcanics. Linear trends on plots of $X$ vs. $Y / X$ and hyperbolic trends on plots of $1 / X$ vs. $Y / X$ cannot be explained by two-component mixing but are consistent with partial melting generating the differences In these highly incompatible element ratios. The range in $\mathrm{Nb} / \mathrm{Th}, \mathrm{La} / \mathrm{Th}$, and $\mathrm{Ba} / \mathrm{Th}$ for the Miocene mafic volcanics and the correlation of these ratios with rock type are given in Table 1. (See Figs. 2 and 3 for symbols and data sources.)

whereas mafic volcanics from islands with enriched (EM) isotopic characteristics (e.g., Gough, Walvis Ridge, and Kerguelen) and group 2 kimberlites have high $\mathrm{La} / \mathrm{Nb}$ and $\mathrm{Ba} / \mathrm{Nb}$ $(>0-8$ and $>12$, respectively, for EM OIB and $>1$ and $>19$, respectively, for group 2 kimberlites). Normal mid-ocean ridge basalts (N-MORB) with $\mathrm{Sr}<0.7025$ have $\mathrm{La} / \mathrm{Nb}>1$ and $\mathrm{Ba} / \mathrm{Nb}<5$. The data for the Miocene volcanics form an elongate field with a positive correlation, displaying extreme variation in both ratios (Fig. 6). One end of the Miocene field completely overlaps the field for HIMU islands and the other end extends well into the field for group 2 kimberlites (EM2). This is exactly the trend we would expect from the $\mathrm{Sr}-\mathrm{Nd}-\mathrm{Pb}$ isotopes, except that the trend is reversed with respect to $\mathrm{SiO}_{2}$ saturation (compare Figs. 1 and 6)! The Miocene nephelinites have $\mathrm{La} / \mathrm{Nb}$ and $\mathrm{Ba} / \mathrm{Nb}$ ratios characteristic of EM2-like 


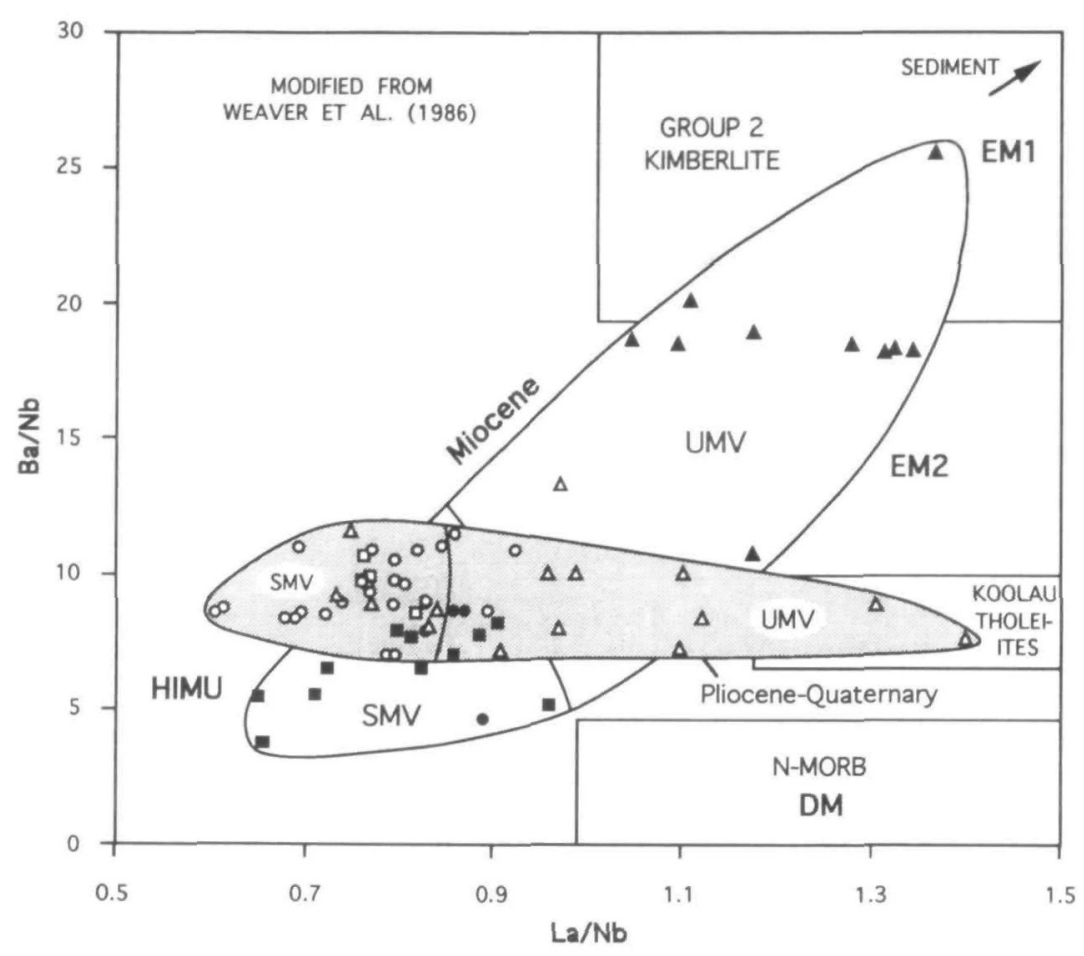

FIG. 6. Plot of La/Nb vs. Ba/Nb for the Miocene and Pliocene-Quaternary mafic volcanics. The Gran Canaria mafic volcanics show extreme variation in both ratios. The variation for this single island (volcano) almost completely covers the entire range in both ratios for OIB samples reported in the literature! The regions for the undersaturated mafic volcanics (UMV) and saturated mafic volcanics (SMV) enclose the same samples as these regions do on the ${ }^{206} \mathrm{~Pb} /{ }^{204} \mathrm{~Pb}$ vs. ${ }^{87} \mathrm{Sr} /{ }^{86} \mathrm{Sr}$ diagram in Fig. 1 . On the $\mathrm{La} / \mathrm{Nb}$ vs. Ba/Nb diagram, the UMV have more EM-like compositions and the SMV more HIMU-like compositions. In contrast, the UMV have more HIMU-like and the SMV more EM-like isotopic compositions (e.g., see Fig. 1). This example clearly illustrates the decoupling of the isotope and trace element systematics. The location of mantle components (HIMU, EM1, and EM2) are based on the trace element composition of ocean islands with end-member isotopic compositions (for summaries, see Sun \& McDonough, 1989; Weaver, 1991). (See Figs. 2 and 3 for symbols and data sources.)

ocean islands and kimberlites, and the Miocene tholeiites and alkali basalts have ratios characteristic of HIMU-like islands. The Miocene tholeiites and alkali basalts, however, have more EM2-like isotopic compositions, and the nephelinites have more HIMU-like isotopic compositions. The Pliocene-Quaternary mafic volcanics form a horizontal trend on the $\mathrm{La} / \mathrm{Nb}$ vs. $\mathrm{Ba} / \mathrm{Nb}$ diagram; the nephelinites and basanites have the highest $\mathrm{La} / \mathrm{Nb}$ ratios and the tholeiites and alkali basalts the lowest. The Koolau tholeiites have similar $\mathrm{La} / \mathrm{Nb}$ and $\mathrm{Ba} / \mathrm{Nb}$ ratios to the Pliocene-Quaternary nephelinites and basanites but have isotopic compositions that fall between DM and EM1 components (Roden et al., 1984), in contrast to the HIMU-like compositions of the Pliocene-Quaternary nephelinites and basanites. The Pliocene-Quaternary tholeiites and alkali basalts have more EM-like isotopic compositions than the nephelinites and basanites but have $\mathrm{La} / \mathrm{Nb}$ and $\mathrm{Ba} / \mathrm{Nb}$ ratios more similar to HIMU-type OIB than the nephelinites and basanites. These relationships, for both the Miocene and Pliocene-Quaternary mafic volcanics, clearly illustrate the decoupling of the incompatible trace element and isotope ratios.

Although the minor variations in isotope ratios appear to reflect lithospheric contamination of some alkali basalts and tholeiites for each age group (Hoernle et al., 1991), the incompatible element ratios appear to be controlled by partial melting. As was shown by 
Clague \& Frey (1982), even small differences in the bulk distribution coefficients of the most incompatible elements can cause ratios of these elements to vary with degree of melting. The largest variation in incompatible element ratios, however, occurs between elements which have large (or relatively large) partition coefficients in accessory phases and those which have small partition coefficients in all source phases: $\mathrm{Zr}, \mathrm{Hf}, \mathrm{Nb}, \mathrm{Ta}, \mathrm{K}, \mathrm{Rb}, \mathrm{Ti}, \mathrm{Pb}, \mathrm{LREE}, \mathrm{U}$, $\mathrm{Th}) /(\mathrm{P}, \mathrm{Sr}, \mathrm{Ba})$ for the Miocene mafic volcanics and $(\mathrm{Zr}, \mathrm{Hf}, \mathrm{Nb}, \mathrm{Ta}, \mathrm{K}, \mathrm{Rb}, \mathrm{Ti}, \mathrm{Pb}) /(\mathrm{LREE}$, $\mathrm{U}, \mathrm{Th}, \mathrm{P}, \mathrm{Sr}, \mathrm{Ba}$ ) for the Pliocene-Quaternary mafic volcanics. The difference in the behavior of incompatible element ratios, such as $\mathrm{Ba} / \mathrm{Nb}, \mathrm{Ba} / \mathrm{Th}, \mathrm{Nb} / \mathrm{Th}, \mathrm{La} / \mathrm{Th}, \mathrm{Ba} / \mathrm{La}, \mathrm{Nb} / \mathrm{Pb}, \mathrm{Nb} / \mathrm{U}$, and $\mathrm{Zr} / \mathrm{Hf}$, with degree of melting (or in the sequence nephelinite to tholeiite) between the Miocene and Pliocene-Quaternary mafic volcanics (Table 1) may result from the presence of an additional accessory phase, possibly zircon, in the Miocene source. In addition to the incompatible element ratios mentioned above, the parent-daughter ratios for the $\mathrm{Sr}, \mathrm{Nd}$, and $\mathrm{Pb}$ isotopic systems also appear to be fractionated by melting (Fig. 4b). Residual phlogopite + ilmenite \pm zircon cannot explain the decrease in $\mathrm{U} / \mathrm{Pb}$ and $\mathrm{Th} / \mathrm{Pb}$ ratios with decreasing $\mathrm{P}_{2} \mathrm{O}_{5} / \mathrm{Al}_{2} \mathrm{O}_{3}$. A residual sulfide phase (Meijer et al., 1990), possibly present as inclusions in olivine and orthopyroxene, or sulfide melt (Sun \& Hanson, 1975b) could preferentially retain $\mathrm{Pb}$ in the source over most of the melting interval. A residual sulfide phase or melt could also explain the compatible behavior of $\mathrm{Cu}$ (Clague \& Frey, 1982), which increases in the Miocene and remains constant in the Pliocene-Quaternary with decreasing $\mathrm{P}_{2} \mathrm{O}_{5} / \mathrm{Al}_{2} \mathrm{O}_{3}$. From the variation in incompatible elements with the $\mathrm{P}_{2} \mathrm{O}_{5} / \mathrm{Al}_{2} \mathrm{O}_{3}$ ratio, we can infer that the relative order of incompatibility in the Miocene source was $\mathrm{Sr}>\mathrm{P}_{2} \mathrm{O}_{5}=$ $\mathrm{Ba}>\mathrm{La}>\mathrm{Ce}>\mathrm{Nd}>\mathrm{Sm}>\mathrm{Eu}>\mathrm{Nb}=\mathrm{Th}=\mathrm{U}=\mathrm{TiO}_{2}>\mathrm{Rb}=\mathrm{K}_{2} \mathrm{O}=\mathrm{Pb}>\mathrm{Hf}>\mathrm{Zr}$ and in the Pliocene-Quaternary source was $\mathrm{Th}=\mathrm{U}>\mathrm{La}>\mathrm{P}_{2} \mathrm{O}_{5}=\mathrm{Sr}=\mathrm{Ce}>\mathrm{Nd}=\mathrm{Ba}=\mathrm{Nb}=\mathrm{Ta}=$ $\mathrm{Pb}>\mathrm{Sm}>\mathrm{Eu}>\mathrm{Rb}=\mathrm{K}_{2} \mathrm{O}=\mathrm{TiO}_{2}=\mathrm{Hr}>\mathrm{Zr}$. In summary, the survival of accessory phases in the residuum and the range in degree of melting appear to control the magnitude of variation in the incompatible element ratios. The magnitude of variation for a cycle appears to be independent of whether the cycle occurred early or late in the evolution of the volcano.

As is illustrated by the hyperbolas on the $1 / X$ plots in Fig. 5 , the incompatible element ratios (of elements with different bulk distribution coefficients) did not become constant until the degree of melting was large enough to form tholeiites in the Miocene and alkali basalts and tholeiites in the Pliocene-Quaternary. Therefore, the incompatible element ratios of only the largest degrees of melting (primarily tholeiites) are similar to that of the source, unless the bulk distribution coefficients for both elements in the ratio are similar over the melting interval. The incompatible element ratios of small-degree melts, however, can be different from that of the source. For example, nephelinite and basanite melts will have lower ${ }^{87} \mathrm{Rb} /{ }^{86} \mathrm{Sr}$ and ${ }^{147} \mathrm{Sm} /{ }^{144} \mathrm{Nd}$ but higher ${ }^{238} \mathrm{U} /{ }^{204} \mathrm{~Pb}$ and ${ }^{232} \mathrm{Th} /{ }^{204} \mathrm{~Pb}$ than their source(s) (Fig. 4b). If isolated for a sufficient period of time, these melts will evolve less radiogenic ${ }^{87} \mathrm{Sr} /{ }^{86} \mathrm{Sr}$ and ${ }^{143} \mathrm{Nd} /{ }^{144} \mathrm{Nd}$ and more radiogenic $\mathrm{Pb}$ isotope ratios compared with their source. This example illustrates that partial melting can fractionate the parent/daughter ratios of the major isotope systems. In conclusion, it is interesting to note that in both age groups the most $\mathrm{SiO}_{2}$-undersaturated mafic volcanics give us the isotopic composition of the source, whereas the most saturated mafic volcanics provide us with the incompatible element ratios of the source.

Based on the above discussion, the interpretation of incompatible element ratios should be treated with caution. As is illustrated by both the Honolulu Volcanics on Oahu and the Miocene and Pliocene-Quaternary mafic volcanics on Gran Canaria (Table 1), partial melting can fractionate ratios of elements highly incompatible in the major mantle phases (olivine, orthopyroxene, clinopyroxene, and garnet), especially if accessory phases, with high partition coefficients for these elements, remain in the residuum. The incompatible element 
ratios of small-degree melts, e.g., nephelinites and basanites, are likely to be significantly different from those ratios in the source, unless the bulk distribution coefficients for the two elements are similar. To minimize the effects of fractionation on these ratios, only largedegree melts, e.g., tholeiites (if available), should be used in studies evaluating (1) the source composition of different OIB end-members and (2) differences in source composition with lithospheric thickness or distance from the mid-ocean ridge. We note, however, that the effect of incompatible element fractionation may be more extreme when melting occurs at great depth under old, thick lithosphere, similar to that beneath the Hawaiian and Canary Islands, as a result of the stabilization of high-pressure accessory phases in the residuum during small and intermediate degrees of melting.

\section{DIFFERENCES IN SOURCE FERTILITY}

As mafic volcanics with similar degrees of $\mathrm{SiO}_{2}$ saturation are presumably formed by similar degrees of partial melting, comparison of the major and trace element compositions of similar basalt types can help elucidate differences in source composition. As minor phases were not in the residuum during generation of most Gran Canaria tholeiites, we will compare major and trace element data of the Miocene and Pliocene tholeiites (Fig. 7). At the same $\mathrm{MgO}$ content, the Miocene tholeiites have higher $\mathrm{CaO}, \mathrm{CaO} / \mathrm{Al}_{2} \mathrm{O}_{3}, \mathrm{CaO} / \mathrm{MgO}, \mathrm{Cr} / \mathrm{Ni}$, $\mathrm{CaO} / \mathrm{Na}_{2} \mathrm{O}, \mathrm{Sc} / \mathrm{Yb}, \mathrm{V}, \mathrm{Sc}, \mathrm{TiO}_{2}, \mathrm{~K}_{2} \mathrm{O}, \mathrm{Zr}, \mathrm{Hf}, \mathrm{Nb}, \mathrm{Ta}, \mathrm{LREE}, \mathrm{Th}, \mathrm{U}$, and $\mathrm{Pb}$, and overall lower $\mathrm{Al}_{2} \mathrm{O}_{3}, \mathrm{Ni}$, and $\mathrm{Zn}$, whereas the data for the other elements show substantial overlap within the analytical uncertainties. The higher $\mathrm{CaO}, \mathrm{CaO} / \mathrm{Al}_{2} \mathrm{O}_{3}, \mathrm{CaO} / \mathrm{MgO}, \mathrm{Cr} / \mathrm{Ni}$, $\mathrm{CaO} / \mathrm{Na}_{2} \mathrm{O}, \mathrm{Sc} / \mathrm{Yb}$, and $\mathrm{Sc}$, and lower $\mathrm{Al}_{2} \mathrm{O}_{3}$ and $\mathrm{Ni}$ in the Miocene tholeiites could reflect (1) derivation from a picritic parent by fractionation of greater amounts of olivine than clinopyroxene as compared with the Pliocene tholeiites and/or (2) derivation from a source with a higher clinopyroxene to olivine ratio, i.e., a more fertile source. The nearly complete absence of clinopyroxene phenocrysts in the Pliocene tholeiites, combined with constant $\mathrm{CaO} / \mathrm{Al}_{2} \mathrm{O}_{3}, \mathrm{CaO} / \mathrm{Na}_{2} \mathrm{O}$, and $\mathrm{Sc} / \mathrm{Yb}$ ratios over the whole range of $\mathrm{MgO}$ contents, is inconsistent with clinopyroxene fractionation, and argues against higher clinopyroxene/olivine ratios in their fractionating assemblage.

There are several possible explanations for the higher abundances of incompatible elements $\left(\mathrm{TiO}_{2}, \mathrm{~K}_{2} \mathrm{O}, \mathrm{Zr}, \mathrm{Hf}, \mathrm{Nb}, \mathrm{Ta}, \mathrm{LREE}, \mathrm{Th}, \mathrm{U}\right.$, and $\left.\mathrm{Pb}\right)$ in the Miocene tholeiites: (1) the Miocene tholeiites were formed at lower degrees of partial melting, (2) the Miocene tholeiites assimilated lithospheric wall-rock during ascent, or (3) the source of the Miocene volcanics was enriched in incompatible elements. As the depths of melting for the Miocene and Pliocene parental magmas were similar (Hoernle \& Schmincke, this volume), the larger volumes and higher melt production rates for the Miocene tholeiites (Fig. 8) are not consistent with the first possibility. As has been shown in the previous section, the behavior of the incompatible elements appears to be decoupled from the isotopic compositions. Interestingly, the incompatible elements and oxides which have higher concentrations in the Miocene tholeiites than the Pliocene tholeiites also have lower concentrations in the Miocene basanites and nephelinites than in both the Miocene tholeiites and the Pliocene basanites and nephelinites. As a result, the trends for the Miocene and Pliocene data cross on binary plots of incompatible elements and of these elements divided by $\mathrm{Al}_{2} \mathrm{O}_{3}$ (Fig. 3). Consistent with the third possible explanation, greater modal percentages of accessory phases in the Miocene source as compared with the Pliocene-Quaternary source could explain the above variations if these phases remained in the residuum to greater degrees of melting in the more fertile source but were no longer residual during formation of the tholeiitic parental melts. Derivation of the Miocene mafic volcanics from a more fertile 

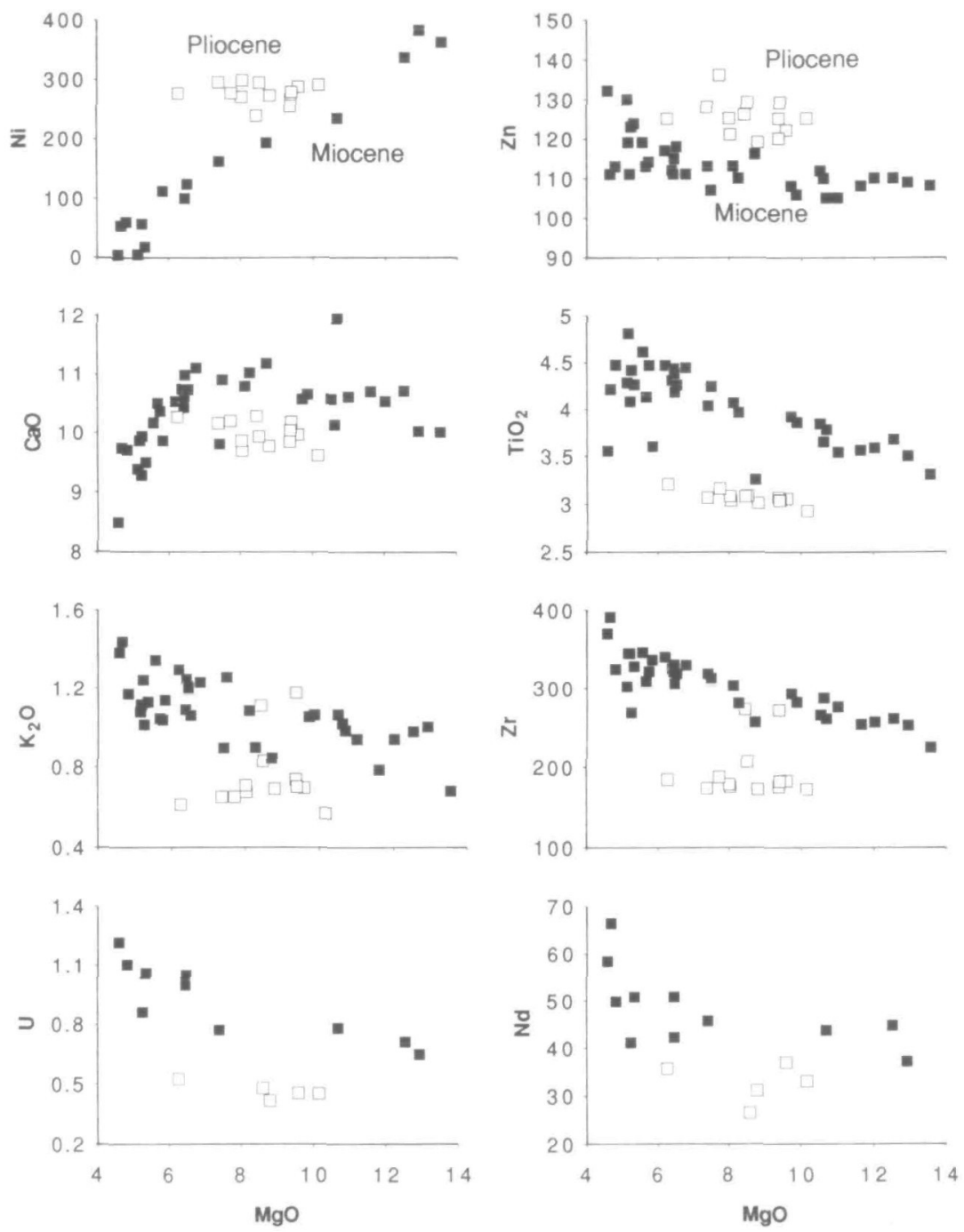

FIG 7. Representative plots of $\mathrm{MgO}$ vs. major (oxides) and trace elements for the Miocene (Q) and Pliocene ( $\square$ ) tholeiites; data for Miocene picrites not shown. The Miocene tholeiites have higher abundances of incompatible and some moderately compatible elements, such as $\mathrm{CaO}, \mathrm{TiO}_{2}, \mathrm{~K}_{2} \mathrm{O}, \mathrm{Zr}, \mathrm{U}$, and $\mathrm{Nd}$, but lower abundances of compatible elements, such as $\mathrm{Ni}$ and $\mathrm{Zn}$, than the Pliocene tholeites. The higher production rates, higher abundances of incompatible elements, and lower abundances of compatible elements in the Miocene tholeiites could result from melting larger volumes of more fertile source material in the Miocene than Pliocene. Symbols and references are the same as in Figs. 2 and 3.

source than the Pliocene-Quaternary mafic volcanics could explain both the compatible and incompatible element differences between the tholeiites, as well as the incompatible element variations with $\mathrm{SiO}_{2}$ saturation for mafic volcanics within an age group and between the Miocene and Pliocene-Quaternary undersaturated mafic volcanics.

A more fertile Miocene than Pliocene-Quaternary source is also consistent with the much larger melt production rates for the Miocene volcanics (Fig. 8) and with the more enriched isotopic composition of the Miocene volcanics. As is illustrated by differences in isotopic composition (Fig. 1), the Miocene and Pliocene-Quaternary volcanics are derived from 


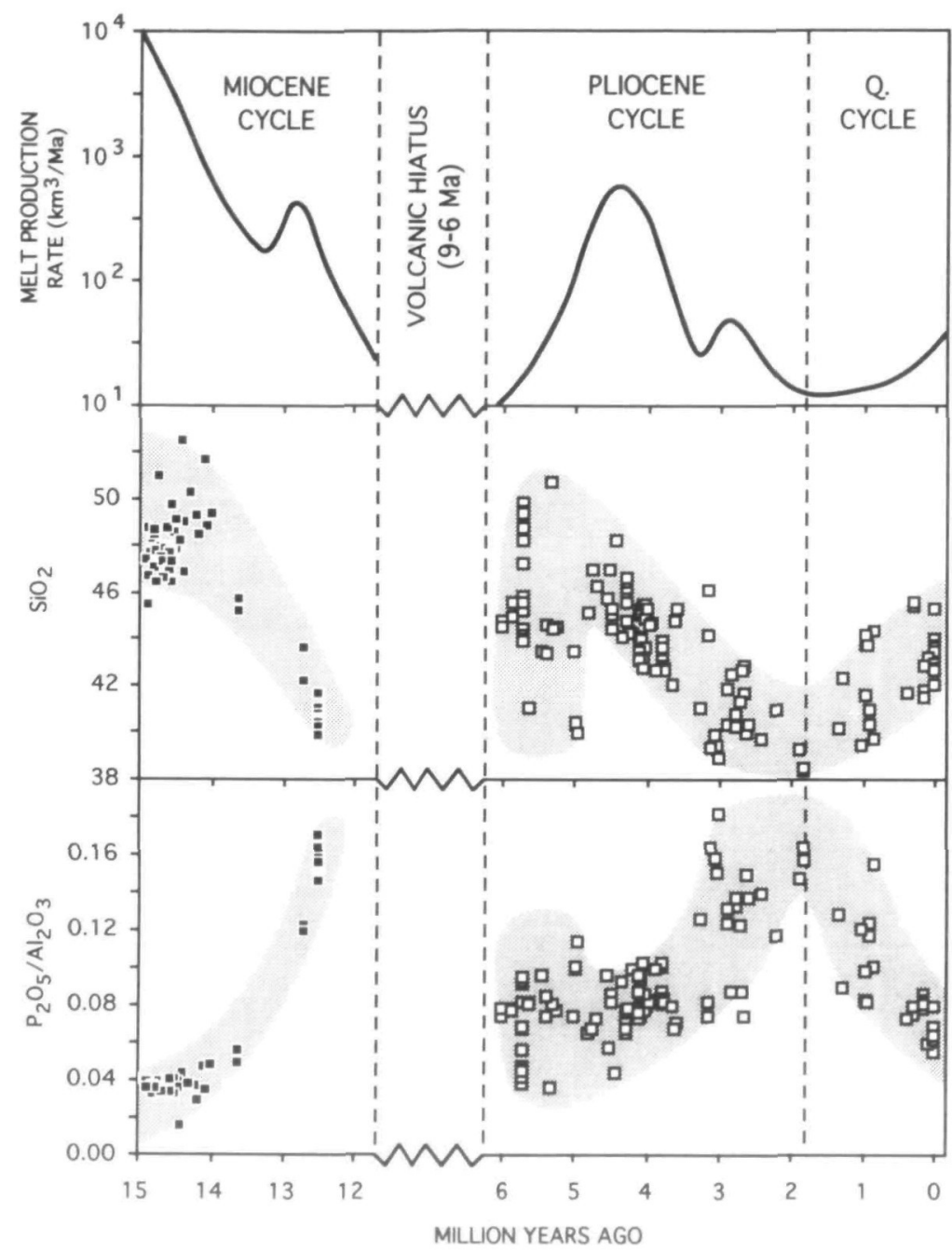

FIo. 8. The temporal variations in melt production rate (=eruption rate corrected for volume loss due to crysta) fractionation), $\mathrm{SiO}_{2}$, and $\mathrm{P}_{2} \mathrm{O}_{5} / \mathrm{Al}_{2} \mathrm{O}_{3}$ of mafic volcanics correlate well for the Miocene, Pliocene, and Quaternary Cycles of volcanism on Gran Canaria. Of the three cycles, only the Pliocene Cycle is completely exposed on Gran Canaria. The earlier part of the Miocene Cycle is submarine and the Quaternary Cycle is probably still in its initial stages. Taken together, an increase in the melt production rate, $\mathrm{SiO}_{2}$ content, and decrease in $\mathrm{P}_{2} \mathrm{O}_{3} / \mathrm{Al}_{2} \mathrm{O}_{3}$ ratio may correspond to an increase in the degree of partial melting in the source. If the Pliocene Cycle is representative, then partial melting initially increases and then decreases for a cycle, possibly reflecting decompression melting of an upwelling blob of hot material from depth. Data sources are the same as in Fig. 3.

distinct sources. If the isotopic composition of the most $\mathrm{SiO}_{2}$-undersaturated mafic volcanics reflects the source composition, then the Pliocene-Quaternary source had less radiogenic $\mathrm{Pb}$ isotopes and slightly more radiogenic $\mathrm{Nd}$ isotopes overall. Two possible explanations for the differences in isotopic composition are (1) a time-integrated depletion in the Pliocene source of $\mathrm{U}$ and $\mathrm{Th}$ relative to $\mathrm{Pb}$ and of $\mathrm{Nd}$ relative to $\mathrm{Sm}$, possibly resulting from an ancient melting event, and (2) mixing of Miocene source material with more depleted mantle to derive the Pliocene-Quaternary source. Both explanations are consistent with a more fertile Miocene source. In conclusion, the major and trace element data, melt production rates, and 
the isotope data are consistent with the derivation of the Miocene volcanics from a more fertile source than the Pliocene-Quaternary volcanics.

\section{EVIDENCE FOR MULTIPLE MELTING EVENTS}

Temporal variations in melt production rate, $\mathrm{SiO}_{2}$ content and the $\mathrm{P}_{2} \mathrm{O}_{5} / \mathrm{Al}_{2} \mathrm{O}_{3}$ ratio of the subaerially erupted mafic volcanics on Gran Canaria are shown in Fig. 8. Ages for undated volcanic samples are estimated on the basis of paleomagnetic data and stratigraphic position (Hoernle \& Schmincke, this volume, table 1). Although the absolute ages may change with improved and more detailed dating studies, the relative sequence for most samples, especially for samples from different formations, should not change. The melt production rate and $\mathrm{SiO}_{2}$ content show remarkably similar patterns, whereas the $\mathrm{P}_{2} \mathrm{O}_{5} / \mathrm{Al}_{2} \mathrm{O}_{3}$ ratio exhibits a mirror image of these patterns. Melt production rate decreased from $\sim 15$ to $9 \mathrm{Ma}$. The $\mathrm{SiO}_{2}$ content of the mafic volcanics decreased and the $\mathrm{P}_{2} \mathrm{O}_{5} / \mathrm{Al}_{2} \mathrm{O}_{3}$ ratio increased from $\sim 15$ to $12 \mathrm{Ma}$. Although only highly evolved volcanics were erupted between 12 and $9 \mathrm{Ma}$, these trachyphonolites and phonolites must have been derived from highly $\mathrm{SiO}_{2}$-undersaturated parental melts. After a hiatus in volcanic activity from 9 to $6 \mathrm{Ma}$, the melt production rate increased gradually, the $\mathrm{SiO}_{2}$ content increased very rapidly, and the $\mathrm{P}_{2} \mathrm{O}_{5} / \mathrm{Al}_{2} \mathrm{O}_{3}$ ratio decreased very rapidly between 6 and $5 \mathrm{Ma}$. The gradual increase in estimated melt production rates, as compared with the chemical parameters, may reflect a higher intrusion to extrusion ratio in the early part of the Pliocene cycle, resulting from passage of these magmas through lithosphere that cooled during the long volcanic hiatus. From $\sim 5$ to $1.8 \mathrm{Ma}$, the melt production rate and $\mathrm{SiO}_{2}$ content decreased and $\mathrm{P}_{2} \mathrm{O}_{5} / \mathrm{Al}_{2} \mathrm{O}_{3}$ increased gradually. Melt production rate and $\mathrm{SiO}_{2}$ content increased and $\mathrm{P}_{2} \mathrm{O}_{5} / \mathrm{Al}_{2} \mathrm{O}_{3}$ ratio decreased again from $1.8 \mathrm{Ma}$ to the present.

From changes in melt production rate, we can divide the volcanic evolution of Gran Canaria into at least two and possibly three volcanic cycles (Schmincke, 1982): a Miocene Cycle, a Pliocene Cycle, and a Quaternary Cycle (Fig. 8). Although the beginning and bulk of the Miocene Cycle is below sea-level, the complete Pliocene Cycle is exposed subaerially. The Quaternary volcanism may mark the beginning of a third cycle (Schmincke, 1982). As has been discussed above, increasing melt production rates, $\mathrm{SiO}_{2}$ contents, and decreasing $\mathrm{P}_{2} \mathrm{O}_{5} / \mathrm{Al}_{2} \mathrm{O}_{3}$ ratios correspond to increasing degrees of partial melting, suggesting that each cycle of volcanism may represent a distinct melting event within the uppermost asthenosphere. This interpretation implies that volcanic gaps or hiatuses, at least in some cases, reflect the absence of fusable material in the source area rather than a compressional stress regime.

A large variety of differentiated volcanics occur after the tholeiitic volcanism in both the Miocene and Pliocene Cycles (see Hoernle \& Schmincke, this volume, fig. 2). In the Miocene Cycle, hawaiites and mugearites overlie the tholeiites, which are in turn overlain by peralkaline rhyolites and trachytes, with rare intercalated tholeiites, alkali basalts, and hawaiites. Trachyphonolite flows with rare basanite and nephelinite flows and dikes follow. Syenites and a trachyphonolite to phonolite cone sheet swarm intrude these rocks (Schmincke, 1990, and references therein). The evolved volcanics can be derived from the associated mafic volcanics through crystal fractionation (Schmincke, 1968, 1976, 1990; Crisp, 1984; Cousens et al., 1990), confirming the trend of decreasing $\mathrm{SiO}_{2}$ saturation observed in the mafic volcanics. In the Pliocene Cycle, complete suites of alkali basalts through trachytes and basanites through phonolites overlie the early mafic volcanics (Hoernle, 1987). The major and trace element data are consistent with fractional crystallization relating compositions within a suite. There is an overall shift from the alkali 
basalt-trachyte suite to the basanite-phonolite suite up section. Increasing differentiation in the later half of a cycle correlates with decreasing degrees of melting, suggesting that a decreasing supply rate results in slower ascent rate and longer periods of stagnation. To summarize, the changes in composition of the evolved volcanics with age correspond to the changes in the mafic volcanic composition with age.

Other Canary Islands also show evidence for multiple cycles of volcanism. Although some of these cycles appear to have had a similar evolution to those on Gran Canaria, for example, the Miocene and Quaternary Cycles on Lanzarote (Armienti et al., 1990), the duration, total volume, maximum eruption rate, and geochemistry of cycles on other islands, for example, La Gomera and Tenerife (Cantagrel et al., 1984; Ancochea et al., 1990), appear to have been different. The duration of cycles on La Gomera ranges from $<1$ to $3 \mathrm{Ma}$. There are two subaerial cycles of volcanism, the upper old basalts and the young basalts and felsic (salic) domes. The lower old basalts contain abundant pillow lavas and thus belong to the submarine or basal complex. The volume of the upper old basalt cycle is similar to the young basalt and felsic dome cycle, but maximum eruption rates for the upper old basalts are significantly lower. As the overall degree of differentiation is greater in the young basalt and felsic dome cycle, correcting for the loss of volume as a result of fractional crystallization processes will result in a higher total volume for the younger cycle. Larger volume and higher maximum eruption rates in the younger cycle are opposite from what is observed on Gran Canaria, suggesting that source fertility or size does not vary systematically with age for cycles. This example illustrates that different islands, as well as different cycles on an island, have had independent volcanic histories, which need to be accounted for in any model for the Canary Islands.

Although only present as clasts in a fanglomerate on Gran Canaria, the submarine or basal complexes (seamount stage) of Fuerteventura, La Gomera, and La Palma have been uplifted and are now subaerially exposed (Schmincke, 1976; Le Bas et al., 1986; Staudigel \& Schmincke, 1984). On La Palma only the upper portion of the basal complex is subaerially exposed; the composition of intrusives and extrusives ranges from trachyte to alkali basalt with decreasing age (Staudigel \& Schmincke, 1984). The basal complex on La Gomera is not well studied. The basal complex on Fuerteventura contains the transition from ocean-floor sedimentation on a continental rise to the beginning of submarine volcanism of an ocean island (Le Bas et al., 1986). The chronology of the basal complex is complex but to a firstorder approximation is as follows: (1) alkalic volcanics, (2) gabbro-pyroxenite-syenite, (3) carbonatite-ijolite-syenite, (4) gabbro-pyroxenite, (5) carbonatite-ijolite-syenite, (6) gabbro-pyroxenite, (7) syenite, nephelinite-basanite-phonolite. Alkalic dikes are pervasive and were intruded throughout the entire submarine history. The three episodes of gabbros have tholeiitic to slightly alkalic affinities. The alternating sequence of alkalic (or highly undersaturated) to tholeiitic (or more saturated) back to alkalic compositions suggests that the basal complexes may also record a history of multiple cycles of magmatic activity.

Because of the long histories of Canarian volcanoes and their episodic growth, an important question concerns the rate of growth of the submarine stage. La Palma has the best exposed basal complex, which also has been well studied (Schmincke \& Staudigel, 1976; Staudigel \& Schmincke, 1984; Staudigel et al., 1986). The complex was formed between 2.9 and $4.0 \mathrm{Ma}$ and extended from near the surface to $\sim 1800-\mathrm{m}$ depth or $2200 \mathrm{~m}$ above the seafloor. Assuming that the part of La Palma between 0- and 1800-m depth was formed in $1 \cdot 1 \mathrm{Ma}$, this part of the seamount was built at a rate of $14000 \mathrm{~km}^{3} / \mathrm{Ma}$. As this average rate is 3-4 times the maximum eruption rate during the subaerial history of Gran Canaria (Hoernle \& Schmincke, this volume, fig. 2), Canarian volcanoes most likely grew at a more rapid rate during at least part of their submarine histories. The age data from the basal complexes of La 
Palma and Fuerteventura, however, indicate that the submarine portions of Canarian volcanoes are formed over millions of years, rather than within half a million years as is commonly accepted for Hawaiian volcanoes.

The evolution of a cycle on Gran Canaria and on other Canary volcanoes is in many ways similar to the evolution of a Hawaiian volcano (Schmincke, 1976, 1982). A model Hawaiian volcano has four major stages of growth (e.g., Clague, 1987; Clague \& Dalrymple, 1987). The earliest or 'pre-shield' stage is believed to be alkalic, based on the assumption that Loihi Seamount, located at the tip of the Hawaiian chain, characterizes the earliest stage of a Hawaiian volcano. The second or 'shield' stage is the most voluminous and contains tholeiites. The 'post-caldera' or 'post-shield' stage is also alkalic, ranging in composition from alkali basalt to trachyte. The fourth ('post-erosional' or 'rejuvenated') stage contains the most undersaturated compositions, which include alkali basalts, basanites, nephelinites, and melilitites. Similar to cycles on a Canary volcano, the parental compositions initially increase in $\mathrm{SiO}_{2}$ saturation and then decrease. The ratio of the volume of tholeiites to alkali mafic volcanics on Hawaiian volcanoes, however, is much greater than on Canarian volcanoes.

\section{AGE PROGRESSION OF THE CANARY ISLANDS}

An east-to-west age progression of the Canary Island chain has long been postulated, based on the ages of subaerially exposed volcanics (Abdel-Monem et al., 1972; Anguita \& Hernan, 1975; McDougall \& Schmincke, 1976). The oldest subaerial volcanics on the two easternmost islands (Lanzarote and Fuerteventura) were erupted at $\sim 20 \mathrm{Ma}$, on the central islands (Gran Canaria, Tenerife, and La Gomera) between 8 and $15 \mathrm{Ma}$, and on the two westernmost islands (La Palma and Hierro) at $<2 \mathrm{Ma}$. A 20-Ma age progression for the Canary Islands yields an average plate motion of $\sim 20 \mathrm{~mm} / \mathrm{yr}$. Data from submarine volcanics and intrusives in the subaerially exposed portions of the basal complexes, however, suggest that the eastern part of the Canary Island chain may be significantly older than $20 \mathrm{Ma}$. K-Ar ages from the Fuerteventura basal complex are as old as $48 \mathrm{Ma}$ for whole rocks (Le Bas et al., 1986), and 38.6 Ma for aegirine-augite (Abdel-Monem et al., 1971) and $35.7 \mathrm{Ma}$ for biotite (Ibarrola et al., 1989) mineral separates. As a result of the high degree of alteration and greenschist facies metamorphism of many basal complex intrusives, these dates are somewhat questionable. Nevertheless, fossil ages for sedimentary layers intercalated with the volcanics indicate that the inception of alkalic volcanism may have occurred in the upper Cretaceous (65-80 Ma) (for a detailed review, see Le Bas et al., 1986). Foraminiferal evidence from the exposed portion of the La Palma basal complex indicates that it was formed at 3-4 Ma (Staudigel et al., 1986). A 65-80-Ma age progression for the Canary Island chain would yield an average plate motion of 5-10 mm/yr. The morphological evolution of the Canary Islands (Schmincke, 1982, fig. 6) and the smaller volumes of the three western volcanoes $\left(<17000 \mathrm{~km}^{3}\right.$ ), compared with the four eastern islands $\left(>23500 \mathrm{~km}^{3}\right.$, Schmincke, 1982), are also consistent with the western islands being at an earlier stage of development than the eastern islands.

\section{MODEL FOR TEMPORAL AND SPATIAL EVOLUTION OF THE CANARY ISLANDS}

\section{Constraints and observations}

The following conclusions and observations place important constraints on any model for the evolution of Gran Canaria and other Canary Islands: 
(1) Volcanism across the entire chain within the last 5000 years requires a melting anomaly $>600 \mathrm{~km}$ in length and $>200 \mathrm{~km}$ in width.

(2) The age data from both the subaerial volcanics and the basal complexes are consistent with an east-to-west age progression in the Canary archipelago.

(3) Canary volcanoes probably grew at a much faster rate during at least part of their submarine than subaerial history.

(4) Each island had an independent growth history.

(5) Melting to form all the Gran Canaria mafic volcanics took place at depths $>100 \mathrm{~km}$; all melts are thus probably derived from upwelling asthenospheric and plume material (Hoernle \& Schmincke, this volume).

(6) Volcanoes (islands) were formed by multiple cycles of volcanism, each of which may represent a distinct melting event.

(7) Different cycles of volcanism were derived from chemically distinct sources.

(8) Periods of volcanic quiescence do not show any systematic age progression along the island chain.

(9) Tholeiites were erupted during the Holocene on the two oldest and easternmost islands (Fuerteventura and Lanzarote).

Movement of the lithosphere over a narrow vertical conduit supplying hotter material from depth can explain the geochemical evolution-from $\mathrm{SiO}_{2}$-undersaturated to $\mathrm{SiO}_{2}$-saturated back to $\mathrm{SiO}_{2}$-undersaturated compositions- of an entire Hawaiian volcano (Chen \& Frey, 1985; Feigenson, 1986; Ribe, 1988; Wyllie, 1988) or of a cycle of volcanism on a Canary Island. Multiple cycles of volcanism on the same island, volcanism on each of the Canary Islands (except La Gomera) within the last 5000 years, and Holocene tholeiites on the two oldest islands, however, require a more complex explanation. Two end-member models are as follows: (1) the lithosphere moves over a line of plumes, with each plume represented by a narrow vertical conduit $\leqslant 100 \mathrm{~km}$ in diameter, or (2) the plume has a narrow vertical conduit at depth that feeds blobs of material into a wide head at the top ( $>600 \mathrm{~km}$ in length and $>200 \mathrm{~km}$ in width). For the first of these models, we would expect (1) each of the islands to have a similar volcanic evolution and (2) the volcanic hiatuses between cycles to have a similar age progression as the inception of volcanism. Neither of these requirements, however, is consistent with the available data. The second model, on the other hand, can satisfy all of the above constraints (Fig. 9).

Recent seismic velocity studies of the upper mantle can place additional constraints on the shape and dimensions of plumes or upwelling regions beneath hotspots. A study by Zhang \& Tanimoto (1992) shows broad low-velocity anomalies ( $>1000 \mathrm{~km}$ in diameter) beneath hotspots which become conduits $(200-400 \mathrm{~km}$ in diameter) at depth. Low-velocity columns for Atlantichotspots--Azores, Iceland, Tristan da Cunha, and Madeira (also on their profile through the Azores)-appear to be bent or elongated towards the east within the upper $200-300 \mathrm{~km}$ of the mantle. We can obtain more specific information about the Canary melting anomaly from a study by Anderson et al. (1992). At $110 \mathrm{~km}$, a broad low-velocity anomaly underlies the Canary Islands, which extends toward the ENE. At a depth of $210 \mathrm{~km}$, the low-velocity anomaly is considerably narrower and directly underlies the Canary Islands, no longer elongated towards ENE. At depths of 310 and $410 \mathrm{~km}$, the Canaries sit on the eastern edge of a broad low-velocity anomaly, which is elongated in a NE-SW direction. Mantle flow could bend plumes during their ascent (Richards \& Griffiths. 1989; Griffiths \& Campbell, 1991). The eastward direction of elongation for the Canaries, Madeira, Azores, and Tristan da Cunha plume heads suggests that asthenospheric flow may be in the direction of plate motion. The low-velocity anomaly beneath Hawaii, which is also elongated towards 


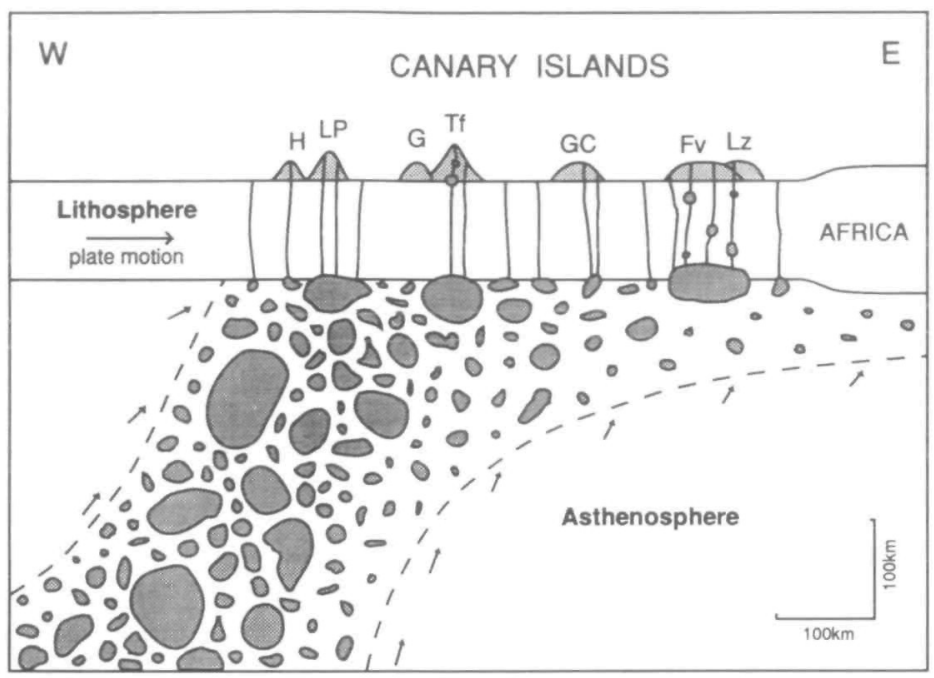

Fic. 9. A 'blob-type' model to explain volcanism in the Canary Islands. The plume beneath the Canary Islands consists of upwelling blobs (HIMU-like) of deeper mantle separated by entrained asthenosphere (DM). At depth $(>200 \mathrm{~km})$, the plume consists of a cylindrical conduit; in the upper asthenosphere, it spreads out along the base of the lithosphere, preferentially in the direction of mantle flow. As is indicated by the arrows, entrainment of asthenosphere can occur at the margins of the plume, primarily along the downstream margin. The largest concentration of material from depth will be above the center of the upwelling conduit, at present between the islands of La Palma and Tenerife. A volcano's highest growth rate (shield stage) will occur while it is over the center of the conduit. Movement of the lithosphere over the center of the conduit is responsible for the age progression of the chain. A cycle of volcanism on an island reflects melting of a blob. If the blob is sufficiently large, tholeiitic melts can be formed in its interior even if it is at the downstream end of the plume head. Volcanic hiatuses reflect intervals when cooler, entrained shallow asthenosphere is in the melting zone beneath an island. As the lithosphere moves the volcano away from the center of the conduit, fewer hot blobs will reach the melting zone beneath the volcano and thus volcanic hiatuses will become more frequent and also possibly longer in duration. Abbreviations: $\mathrm{H}-\mathrm{H}$ erro,

LP-La Palma, G-La Gomera, Tf-Tenerife, GC-Gran Canaria, F-Fuerteventura, Lz-Lanzarote.

the east or in the opposite direction of the plate motion, graphically illustrates, however, that there is not necessarily a correlation between elongation direction and plate motion.

\section{A blob model for the origin of the Canary Islands}

We propose the following model to explain volcanism in the Canary Islands (Fig. 9). A conduit with radius of $\sim 100-200 \mathrm{~km}$ rises vertically from a depth of $>400 \mathrm{~km}$. Between depths of 100 and $200 \mathrm{~km}$, the conduit bends or spreads out towards the east, producing a broad region of upwelling ( $>600 \mathrm{~km}$ long and $>200 \mathrm{~km}$ wide) beneath the entire Canary chain. The top of the plume, or plume head, consists of two primary components: (1) blobs of material from depth (>400 km) and (2) entrained upper-mantle (asthenospheric) material and melts. The size of the blobs, probably $<100 \mathrm{~km}$ in diameter, and the ratio of blob material to entrained material in any region of the plume head will vary. The shift in isotopic composition of the more $\mathrm{SiO}_{2}$-undersaturated mafic volcanics to more depleted compositions with both decreasing age on an island and increasing distance from the western or younger end of the chain at any given age suggest, however, that more asthenospheric material is entrained on the downstream side of the plume head (Hoernle \& Tilton, 1991). The higher ratio of hotter plume material from depth to cooler entrained asthenosphere at the upstream end of the plume could explain higher melt production and growth rates during the submarine evolution of the volcano than during its later subaerial history. If 
asthenospheric flow is in the same direction as the elongation of the plume head, it may serve to winnow out small blobs from the upstream end of the plume head and carry them to the downstream end. This process could provide another explanation for lower overall growth rates during subaerial volcanism vs. submarine volcanism.

According to our model, a cycle of volcanism on a volcano represents decompression melting of a blob of hotter material from depth. The first melts in a cycle are low-degree, $\mathrm{SiO}_{2}$-undersaturated melts from the cooler, upper margin of the blob. These volatile-rich melts rise rapidly through the lithosphere, possibly facilitated by magma- and volatileinduced crack propagation (Spera, 1984; Wyllie, 1988). They erupt on the surface having undergone little differentiation or interaction with the lithosphere (Hoernle et al., 1991). As the center of the blob moves into the melting zone, larger degrees of melting in the hotter core of the blob produce more saturated melts. If the size of the blob and its internal temperature are large enough, picritic melts may be formed. As they have larger volumes and are volatile poor, these melts may pool at or within the base of the lithosphere, fractionating and assimilating lower lithosphere (Sen \& Jones, 1990; Hoernle et al., 1991) and small-degree melts formed at the margins of the bloh. The more saturated melts also travel more slowly to the surface than the more undersaturated melts, spending time in shallower mantle and crustal reservoirs where they evolve into tholeiites through olivine \pm clinopyroxene fractionation (Hoernle \& Schmincke, this volume). Eventually, the residual core of the blob is pushed aside and replaced by the cooler, lower margin of the blob. The degree of melting decreases, reflected in a decrease in magma supply to the shallow reservoirs and increasing $\mathrm{SiO}_{2}$ undersaturation of the volcanics. If these melts use the plumbing system established by the more voluminous tholeiites, as may have occurred at the end of the Miocene Cycle, they will stagnate longer and thus fractionate to greater degrees as the melt supply decreases (Clague, 1987; Hoernle, 1987). If, on the other hand, these lower-volume, more volatile-rich magmas bypass the main magma plumbing system, as may have occurred during the Pliocene Cycle, they may erupt having undergone relatively little fractionation, as is often the case with volcanics erupted on the edges of the island or flanks of the volcano.

This blob model can accommodate considerable variation in the duration, total volume, maximum eruption rate, and geochemistry of cycles. If a blob rises directly beneath an island, then melts formed in the core of the blob; at maximum degrees of melting, are likely to erupt on the island in the middle of the cycle. If, however, only the edge of the blob is beneath the island, only highly undersaturated melts may reach the surface of the island, even during the middle of the cycle. The more saturated melts from the core may be erupted on the submarine flanks of the volcano or on the ocean floor (Clague et al., 1990), if they do not form intrusive bodies. Melts, however, may preferentially reach the surface in areas where the lithosphere has already been thermally weakened, thus capping volcanoes formed by older blobs. The size, temperature, and composition (fertility) of the blob will also affect the range in compositions erupted during the cycle. Interactions between blobs beneath an island can result in complex, non-systematic patterns, as are observed on some of the Canary Islands. The blob model is also capable of easily explaining the historic eruption of basanites on the two youngest and westernmost islands, and of Holocene tholeiites on the two oldest and easternmost islands. For example, the core of a big blob could at present be melting beneath the easternmost islands, whereas small blobs or the upper, outer, or lower margins of big blobs could be melting beneath the two westernmost islands. The model also suggests that $\mathrm{SiO}_{2}$-undersaturated melts are more likely melt products than saturated melts, consistent with what has been observed in the Canary Islands.

Volcanic hiatuses or gaps in volcanism could represent periods when either relatively cool, entrained shallow asthenosphere or residual plume material is within the melting zone 
beneath the island. According to the calculations of Watson \& McKenzie (1991), melt production extends to a depth of $\sim 136 \mathrm{~km}$ in the Hawaiian Plume. As it is unlikely that the Canary Plume is hotter than the Hawaiian Plume, this estimate serves as a maximum depth of melting in the Canary Plume. If the mechanical boundary layer is $\sim 100 \mathrm{~km}$ thick beneath the Canaries (Hoernle \& Schmincke, this volume), the zone of possible melting is $\leqslant 36 \mathrm{~km}$ thick. Alternatively, volcanic hiatuses could reflect periods of intrusion rather than extrusion, as a result of magma systematics or a compressive stress regime in the lithosphere.

As a final note, we would like to emphasize that we do not necessarily envision sharp boundaries between different types of plume material, as is implied by the term 'blob'. It is more likely that the boundaries between regions of deep material and entrained shallow material are gradational. The most important feature of the 'blob model' is to illustrate the heterogeneity, both in temperature and composition, within the plume.

\section{CONCLUSIONS}

Distinctive differences have long been noted between Pacific and Atlantic hotspots. These include the longer life and more complex evolution of the Atlantic Ocean islands. The Canary Islands illustrate these complexities well. The most obvious tectonic difference between the Atlantic and Pacific is the significantly slower rates of plate motion in the Atlantic, which no doubt provide part of the explanation for the longer life and added complexity of Atlantic volcanoes (Schmincke, 1973). Recent seismic velocity maps (Zhang \& Tanimoto, 1992) suggest an additional explanation. The apparent elongation of Atlantic plume heads to the east is in a similar direction or oblique to plate motion. For this reason, the older islands in the chain will remain over the plume head for long periods of time, tens of millions of years. As is illustrated by seismic profiles for Hawaii, however, the elongation of the plume head is towards the east, in the opposite direction of plate motion. The youngest volcanoesKilauea and Loihi-appear to be forming on the western end of the plume head, which lies above the conduit supplying material from the deeper mantle. Therefore the volcano will be carried away from the plume head relatively quickly after the shield stage, especially as the rate of plate motion is so high. Thereafter, the only available plume material is carried at the base of the lithosphere, just below the mechanical boundary layer. Although this material may be sufficient to produce low levels of highly undersaturated 'post-erosional' or 'rejuvenated' volcanics, additional cycles of volcanism, which include $\mathrm{SiO}_{2}$-saturated compositions, are not possible. Clearly, more seismic velocity data are necessary to determine and define better the shapes of plume heads and to determine the locations and dimensions of the conduits that feed these plume heads. The present resolution of seismic studies, however, is on the order of hundreds of kilometers. Petrologic and geochemical studies of intraplate volcanoes are thus essential for detecting smaller structures, such as blobs of $<100-\mathrm{km}$ diameter, as well as for testing larger-scale seismic models.

\section{ACKNOWLEDGEMENTS}

This study represents part of both a Ph.D. dissertation (completed at the University of California Santa Barbara) and postdoctoral study (completed at the University of California Santa Cruz) by K.H. The manuscript was greatly improved by comments from Frank Spera, Jim Mattinson, John Lupton, David Graham, Brian Cousens, Al Hofmann, D. Latin, and A. le Roex. We also would like to extend special thanks to George Tilton for his financial support and intellectual stimulation, without which this project could not have been completed. This research was in part supported by NSF grant EAR88-17802 to George 
Tilton and NSF grant EAR91-05113 to K.H., and by the Forschungsgemeinshaft (Leibnitz grant) to H.U.S. We are grateful to Rodey Batiza, Pat Castillo, Jan Hertogen, and Bob Walker for providing us with INAA data. Funds for XRF analyses and for INAA at Oregon State University Radiation Center were provided by the US Department of Energy's University Reactor Sharing Program.

\section{REFERENCES}

Abdel-Monem, A., Watkins, N. D., \& Gast, P. W., 1971. Potassium-argon ages, volcanic stratigraphy, and geomagnetic polarity history of the Canary Islands: Lanzarote, Fuerteventura, Gran Canaria, and La Gomera. Am. J. Sci. 271, 490-521.

1972. Potassium-argon ages, volcanic stratigraphy, and geomagnetic polarity history of the Canary Islands; Tenerife, La Palma, and Hierro. Ibid. 272, 805-25.

Adam, J., 1988. Dry, hydrous, and $\mathrm{CO}_{2}$-bearing liquidus phase relationships in the CMAS system at $28 \mathrm{~kb}$, and their bearing on the origin of alkali basalts. J. Geol. 96, 709-19.

Ancochea, E., Fuster, J. M., Ibarrola, E., Cendrero, A., Coello, J., Hernan, F., Cantagrel, J. M., \& Jamond, C., 1990. Volcanic evolution of the island of Tenerife (Canary Islands) in the light of new K-Ar data. J. Volcanol. Geotherm. Res. 44, 231-49.

Anderson, D. L., Tanimoto, T., \& Zhang, Y.-S., 1992. Plate tectomics and hotspots: the third dimension. Science 256, 1601-1732.

Anguita, F., \& Hernan, F., 1975. A propagating fracture model versus a hot spot origin for the Canary Islands. Earth Planet. Scl. Lett. 27, 11-19.

Armienti, P., Innocenti, F., Pasquare, G., \& Tonarinı, S., 1990. Petrogenesis of the basaltic lavas of Lanzarote Canary Islands. Abstracts volume. Mainz: IAVCEI.

Brey, G., 1978. Origin of olivine-melilitites-chemical and experimental constraints. J. Volcanol. Geotherm. Res. 3, 61-88.

- Green, D. H., 1977. Systematic study of liquidus phase relations in olivine melilitite $+\mathrm{H}_{2} \mathrm{O}+\mathrm{CO}_{2}$ at high pressures and petrogenesis of an olivine melilitite magma. Contr. Miner. Petrol. 61, 141-62.

Cantagrel, J. M., Cendrero, A., Fuster, J. M., Ibarrola, E., \& Jamond, C., 1984. K-Ar chronology of the volcanic eruptions in the Canarian Archipelago: island of La Gomera. Bull. Volcanol. 43, 597-609.

Chen, C. Y., \& Frey, F. A. 1985. Trace element and isotopic geochemistry of lavas from Haleakala Volcano, East Maui, Hawaii: implications for the origin of Hawaiian mafic volcanics. J. Geophys. Res. 90, 8743-68.

Clague, D. A., 1987. Hawaiian alkaline volcanism. In: Fitton, J. G. \& Upton, B. G. J. (eds.) Alkaline Igneous Rocks. Geol. Soc. Spec. Publ. 30, 227-52.

- Dalrymple, G. B., 1987. The geology of the Hawaiian-Emperor Volcanic Chain. US Geol. Surv. Prof. Paper 1350, 5-49.

— Frey, F. A., 1982. Petrology and trace element geochemistry of the Honolulu Volcanics, Oahu: implications for the oceanic mantle below Hawaii. J. Petrology 23, 447-504.

- Holcomb, R. T., Sinton, J. M., Detrick, R. S., \& Torresan, M. E., 1990. Pliocene and Pleistocene alkalic flood mafic volcanics on the seafloor north of the Hawaiian islands. Earth Planet. Sci. Lett. 98, 175-91.

Cousens, B. L. 1990. Isotope geochemistry of lavas and pyroclastic flows of the Mogan and lower Fataga Formations, Gran Canaria, Canary Islands. Unpublished Ph.D. Thesis, University of California, Santa Barbara, 148 pp.

- Spera, F.J.\& Tilton, G. R., 1990. Isotopic patterns in silicic ignimbrites and lava flows of the Mogan and lower Fataga Formations, Gran Canaria, Canary Islands: temporal changes in mantle source composition. Earth Planet. Sci. Lett. 96, 319-35.

Crisp, J. A., 1984. The Mogan and Fataga Formations of Gran Canaria (Canary Islands): geochemistry, petrology, and compositional zonation of the pyroclastic and lava flows; intensive thermodynamic variables within the magma chamber; and the depositional history of pyroclastic flow E/ET. Ph.D. Thesis, Princeton University, 304 pp.

Duncan, R. A., 1981. Hotspots in the Southern Oceans-an absolute frame of reference for the motion of the Gondwana continents. Tectonophysics 74, $29-42$.

Falloon, T. J., \& Green, D. H., 1988. Anhydrous partial melting of peridotite from 8 to $35 \mathrm{~kb}$ and the petrogenesis of MORB. J. Petrology, Special Lithosphere Issue, $279-414$.

Hatton, C. J., \& Harris, K. L., 1988. Anhydrous partial melting of a fertile and depleted peridotite from $2-30 \mathrm{~kb}$ and application to mafic volcanic petrogenesis. J. Petrology 29, 1257-82.

Feigenson, M. D., 1986. Constraints on the origin of Hawaiian lavas. J. Geophys. Res. 91, 9383-93.

Frey, F. A., Wise, W. S., Garcia, M. O., West, H., Kwon, S. T., \& Kennedy, A., 1990. Evolution of Mauna Kea Volcano, Hawaii: petrologic and geochemical constraints on Postshield volcanism. J. Geophys. Res. 95(B2), $1271-300$.

Fujimaki, H., 1986. Partition coefficients of $\mathrm{Hf}, \mathrm{Zr}$, and $\mathrm{REE}$ between zircon, apatite, and liquid. Contr. Miner. Petrol. 94, 42-5. 
Green, T. H., 1981. Experimental evidence for the role of accessory phases in magma genesis. J. Volcanol. Geotherm. Res. 10, 405-22.

Greenough, J. D., 1988. Minor phases in the Earth's mantle: evidence from trace- and minor-element patterns in primitive alkaline magmas. Chem. Geol. 69, 177-92.

Griffiths, R. W., \& Campbell, I. H., 1991. On the dynamics of long-lived plume conduits in the convecting mantle. Earth Planet. Sci. Lett. 103, 214-27.

Hanson, G. N., 1980. Rare earth elements in petrogenetic studies of igneous systems. Ann. Rev. Earth Planet. Sci.8, $371-406$.

- 1990. An approach to trace element modeling using a simple igneous system as an example. In: Mineralogical Society of America Short Course. Washington, DC: Mineralogical Society of America, 79-97.

Hawkesworth, C. J., Kempton, P. D., Rogers, N. W., Ellam, R. M., \& van Calsteren, P. W., 1990. Continental mantle lithosphere, and shallow level enrichment processes in the Earth's mantle. Earth Planet. Sci. Lett. 96, 256-68.

Hoernle, K. A., 1987. General geology and petrology of the Roque Nublo Volcanics on Gran Canaria, Canary Islands, Spain. Unpublished M.A. Thesis, University of California, Santa Barbara, 191 pp.

- Tilton, G., 1991. Sr-Nd-Pb isotope data for Fuerteventura (Canary Islands) basal complex and subaerial volcanics: applications to magma genesis and evolution. Schweiz. Miner. Petrogr. Mitt. 71, 3-18.

- Schmincke, H.-U., 1991. Sr-Nd-Pb isotopic evolution of Gran Canaria: evidence for shallow enriched mantle beneath the Canary Islands. Earth Planet. Sci. Lett. 106, 44-63.

Hofmann, A. W., Jochum, K. P., Seufert, M., \& White, W. M., 1986. Nb and Pb in oceanic basalts: new constraints on mantle evolution. Earth Planet. Sci. Lett. 79, 33-45.

Ibarrola, E., Fuster, J. M., \& Cantagrel, J. M., 1989. Edades K-Ar de las rocas volcanicas submarinas en el sector norte del complejo basal de Fuerteventura. E.S.F. Meeting on Canarian Volcanism. Madrid: Cabildo Insular, 124-9.

lrving, A. J., 1978. A review of experimental studies of crystal/liquid trace element partitioning. Geochim. Cosmochim. Acta 42, 743-70.

- Frey, F. A., 1984. Trace element abundances in megacrysts and their host mafic volcanics: constraints on partition coefficients and megacryst genesis. Ibid. 48, 1201-21.

Jacques, A. L., \& Green, D. H., 1980. Anhydrous melting of peridotite at 0-15 kbar pressure and the genesis of tholeiitic mafic volcanics. Contr. Miner. Petrol. 73, 287-310.

Jochum, K. P., Hofmann, A. W., Ito, E., Seufert, H. M., \& White, W. M., 1983. K, U, and Th in mid-ocean ridge basalt glasses and heat production, $\mathrm{K} / \mathrm{U}$ and $\mathrm{K} / \mathrm{Rb}$ in the mantle. Nature 306, 431-6.

Jones, A. P., \& Wyllie, P. J., 1984. Minor elements in perovskite from kimberlites and distribution of the rare earth elements: an electron probe study. Earth Planet. Sci. Lett. 69, 128-40.

Le Bas, M. J., 1978. Are olivine-poor nephelinites a primary melt product from the mantle? Bull. Volcanol. 41, 463-5.

- Rex, D. C., \& Stillman, C. J., 1986. The early magmatic chronology of Fuerteventura, Canary Islands. Geol. Mag. 123(3), 287-98.

Marcelot, G., Dupuy C., Dostal, J., Rancon, J. P., \& Pouclet, A., 1989. Geochemistry of mafic volcanic rocks from the Lake Kivu (Zaire and Rwanda) section of the western branch of the African Rift. J. Volcanol. Geotherm. Res. 39, 73-88.

McDougall, I., \& Schmincke, H.-U., 1976. Geochronology of Gran Canaria, Canary Islands: age of shield building volcanism and other magmatic phases. Bull. Volcanol. 40,1-21.

Meijer, A., Kwon, T. T., \& Tilton, G. R., 1990. U-Th-Pb partitioning behavior during partial melting in the upper mantle: implications for the origin of high mu components and the 'Pb paradox'. J. Geophys. Res. 9S(B1), $433-48$.

Meyer, H. O. A., \& Tsai, H. M., 1976. Mineral inclusions in natural diamond-their nature and significance: a review. Miner. Sci. Eng. 8, 242-61.

Morgan, W. J., 1983. Hotspot tracks and the early rifting of the Atlantic. Tectonophysics 94, 123-39.

O'Reilly, S. Y., Griffin, W. L., \& Ryan, C. G., 1991. Residence of trace elements in metasomatized spinel lherzolite xenoliths: a proton-microprobe study. Contr. Miner. Petrol. 109, 98-113.

Palacz, Z. A., \& Saunders, A. D., 1986. Coupled trace element and isotope enrichment in the Cook-Austral-Samoa islands, southwest Pacific. Earth Planet. Sci. Lett. 79, 270-80.

Raber, E., \& Haggerty, S. E., 1979. Zircon-oxide reactions in diamond-bearing kimberlites. In: Boyd, F. R., \& Meyer, H. O. A. (eds.) The Mantle Sample: Inclusions in Kimberlites and Other Volcanics. Am. Geophys. Union, Proc. 2nd Int. Kimberlite Conf. 1, 229-40.

Ribe, N. M., 1988. Dynamical geochemistry of the Hawaiian plume. Earth Planet. Sci. Lett. 88, 37-46.

Richards, M. A., \& Griffiths, R. W., 1989. Thermal entrainment by deflected mantle plumes. Nature 342, 900-2.

Roden, M. F., Frey, F. A., \& Clague, D. A., 1984. Geochemistry of tholeiite and alkalic lavas from the Koolau Range, Oahu, Hawaii: implications for Hawaiian volcanism. Earth Planet. Sci. Lett. 66, 407-26.

Schmincke, H.-U., 1968. Faulting versus erosion and the reconstruction of the Mid-Miocene shield volcano of Gran Canaria. Geol. Mitt. 8, 23-50.

1973. Magmatic evolution and tectonic regime in the Canary, Madeira and Azores Island Groups. Geol. Soc. Am. Bull. 84, 633-48. 
1976. The geology of the Canary Islands. In: Kunkel, G. (ed.) Biogeography and Ecology of the Canary Islands. The Hague: Junk, 67-184.

1982. Volcanic and chemical evolution of the Canary Islands. In: von Rad, U., Hinz, K., Sarnthein, M., \& Seibold, E. (eds.) Geology of the Northwest African Margin. New York: Springer-Verlag, 273-306.

1987-1990. Geological Field Guide of Gran Canaria. Witten, Germany: Pluto Press, 1-210.

Flower, M. F. J., 1974. Magmenevolution auf Atlantischen Vulkaninseln. Naturwissenschaften 61, $288-92$.

Staudigel, H., 1976. Pillow lavas on central and eastem Atlantic Islands. Bull. Soc. Géol. Fr. 18, 870-83.

Sen, G., \& Jones, R. E., 1990. Cumulate xenolith in Oahu, Hawaii: implications for deep magma chambers and Hawaiian volcanism. Science $249,1154-7$.

Sleep, N. H., 1990. Hotspots and mantle plumes: some phenomenology. J. Geophys. Res. 95, 6715-36.

Spera, F. J., 1984. Carbon dioxide in petrogenesis, III, role of volatiles in the ascent of alkaline magma with special reference to xenolith-bearing mafic lavas. Contr. Miner. Petrol. 88, 217-32.

Staudigel, H., Feraud, G., \& Giannerini, G., 1986. The history of intrusive activity on the island of La Palma (Canary Islands). J. Volcanol. Geotherm. Res. 27, 299-322.

_ Schmincke, H.-U., 1984. The Pliocene seamount series of La Palma (Canary Islands). J. Geophys. Res. 89, $11195-215$.

Sun, S.-S., \& Hanson, G. N., 1975a. Evolution of the mantle: geochemical evidence from alkali basalt. Geology 3, 297-300.

1975b. Origin of Ross Island basanitords and limitations upon the heterogeneity of mantle sources for alkali basalts and nephelinites. Contr. Miner. Petrol. 52, 77-106.

- McDonough, W. F., 1989. Chemical and isotopic systematics of oceanic basalts: implications for mantle composition and processes. In: Saunders, A. D., \& Norry, M. J. (eds.) Magmatism in the Ocean Basins. Geol. Soc. Spec. Publ. 42, 313-45.

Takahashi, E., \& Kushiro, I., 1983. Melting of a dry peridotite at high pressures and mafic volcanic magma genesis. Am. Miner. 68, 859-79.

Watson, E. B., 1980. Apatite and phosphorus in mantle source regions: an experimental study of apatite/melt equilibria at pressures to $25 \mathrm{kbar}$. Earth Planet. Sct. Lett. 51, 322-35.

Watson, S., \& McKenzie, D., 1991. Melt generation by plumes: a study of Hawaiian volcanism. J. Petrology 32, $501-37$

Weaver, B. L., 1991. The origin of ocean island basalt end-member compositions: trace element and isotopic constraints. Earth Planet. Sci. Lett. 104, 381-97.

- Wood, D.A., Tarney, J., \& Joron, J.-L., 1986. Role of subducted sediment in the genesis of ocean island basalts: geochemical evidence from South Atlantic Ocean islands. Geology 14, $275-8$.

Wilson, J. T., 1963. A possible origin of the Hawaiian Islands. Can. J. Phys. 41, 863-70.

Wyllie, P. J., 1988. Solidus curves, mantle plumes, and magma generation beneath Hawaii. J. Geophys. Res. 93(B5), 4171-81.

Zhang, Y.-S., \& Tanimoto, T., 1992. Ridges, hotspots and their interaction as observed in seismic velocity maps. Nature 355, 45-9.

Zindler, A., \& Hart, S., 1986. Chemical geodynamics. Ann. Rev. Earth Planet. Sci. Lett. 14, 493-571. 